\title{
COMPARATIVE ANALYSIS OF MONETARY ESTIMATES OF EXTERNAL ENVIRONMENTAL COSTS ASSOCIATED WITH COMBUSTION OF FOSSIL FUELS
}

Jonathan Koomey

\author{
Energy Analysis Program \\ Applied Science Division \\ Lawrence Berkeley Laboratory \\ University of California \\ Berkeley, CA 94720
}

July 1990

The work described in this paper was funded by the Assistant Secretary for Conservation and Renewable Energy, Office of Utility Technologies of the U.S. Department of Energy, under Contract ivo. DE-AC03-76SF00098. 


\section{TABLE OF CONTENTS}

EXECUTIVE SUMMARY

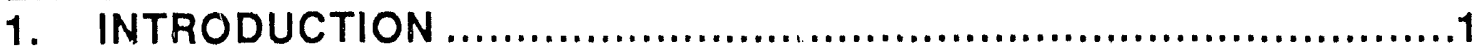

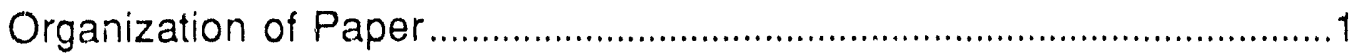

2. BACKGROUND ............................................................

Framework for Comparison and Scope of the Analysis ............................ 1

Methods of Calculating External Costs....................................................... 5

Pitfalls in Externality Analysis ...................................................................6

3. DESCRIPTION OF DIFFERENT ESTIMATES $\ldots \ldots \ldots \ldots \ldots \ldots \ldots \ldots . \ldots \ldots$

Direct Damage Estimation ....................................................................

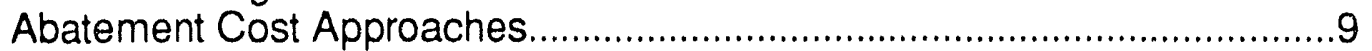

Regulatory Determinations ……………………….................................... 11

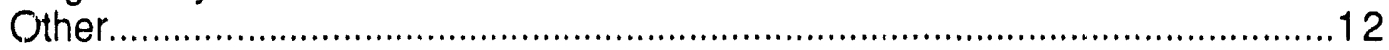

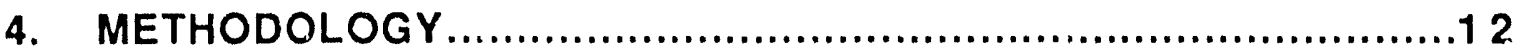

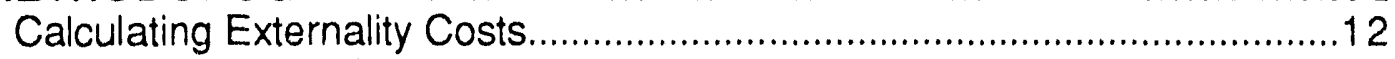

Marginal Dairiage Costs.............................................................................13

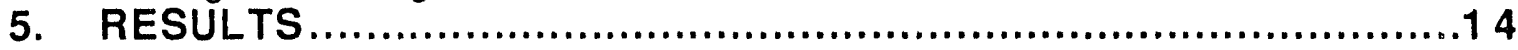

New Power Plants .............................................................................. 14

Existing Power Plants ...........................................................................19

Direct Combustion of Oil and Gas ...........................................................22

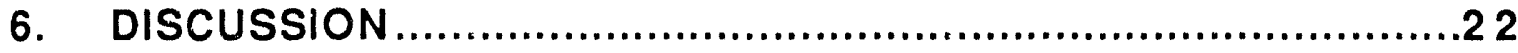

The NY State Bidding Systems.............................................................22

Site-Specificity of Damages .......................................................................26

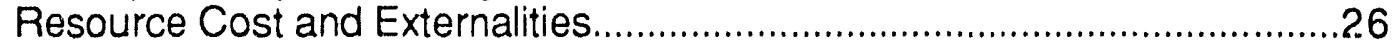

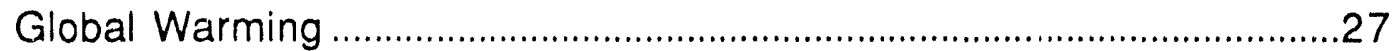

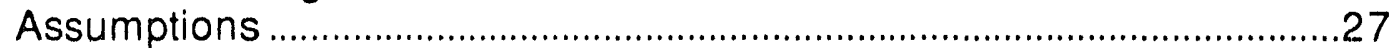

The Need for Consistent Emissions Factors.............................................27

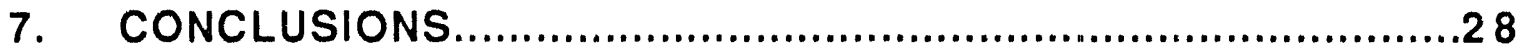

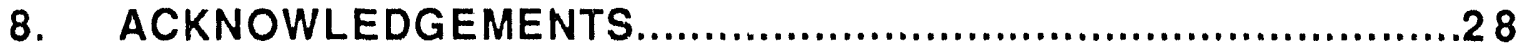

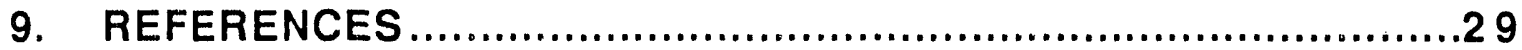

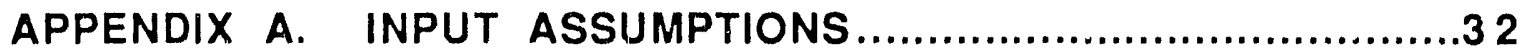

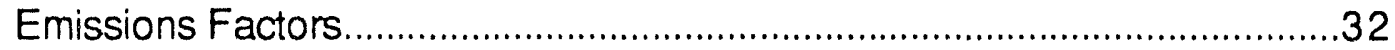

Power Plant Cost Assumptions ...................................................................32

APPENDIX B. CALCULATING EXTERNAL COSTS USING THE NYPSC'S WORKSHEETS. 


\section{LIST OF TABLES}

Page

TABLE 1. ENVIRONMENTAL INSULTS FROM FOSSIL FUELS …................ 4

TABLE 2. OVERVIEW OF EXTERNALITY STUDIES .................................. 8

TABLE 3. VALUE OF INCREMENTAL EMISSIONS REDUCTIONS $(1989 \$ / L B)$

TABLE 4. EXTERNALITIES FROM NEW NSPS POWER PLANTS (1989 $\Phi / k W h)$

TABLE 5. EXTERNALITIES FROM NEW NSPS POWER PLANTS (TOTAL. AS \% OF DELIVERFD COST).

TABLE 6. EXTERNAL COSTS FROM EXISTING U.S. STEAM POWER PLANTS IN 1988 (1989๕/KWH)

TABLE 7. EXTERNALITIES FROM EXISTING U.S. STEAM POWER PLANTS IN 1988 (TOTAL AS \% OF DELIVERED COST)

TABLE 8. EXTERNALITIES FROM DIRECT USE OF NATURAL GAS (\$/MMBTU OF FUEL INPUT)

TABLE 9. EXTERNALITIES FROM DIRECT USE OF OIL (\$MMBTU OF FUEL INPUT).

TABLE 10. EXTERNALITIES FROM DIRECT USE OF FOSSIL FUELS (TOTAL AS \% OF 1988 PRICE)

TABLE A.1. EMISSIONS FACTORS (LBS/MMBTU OF FUEL USE)

TABLE A.2. CALCULATING SULFUR EMISSIONS FROM OIL AND COAL.

TABLE A.3. NEW SUPPLY TECHNOLOGIES 35

\section{LIST OF FIGURES}

Page

FIGURE 1. STEPS IN ENERGY PRODUCTION, PROCESSING, AND USE

FIGURE 2. INSULTS, PATHWAYS, STRESSES, AND ENVIRONMENTAL COSTS. 


\section{EXECUTIVE SUMMARY}

Public utility commissions in a number of states have begun to explicitly treat costs of environmental externalities in the resource planning and acquisition process (Cohen et al. 1990). This paper compares ten different ostimates and regulatory determinations of external environmental costs associated with fossil fuel combustion, using consistent assumptions about combustion efficiency, emissions factors, and resource costs. This consistent comparison is useful because it makes explicit the effects of various assumptions. This paper uses the results of the comparison to illustrate pitfalls in calculation of external environmental costs, and to derive lessons for design of policies to incorporate these externalities into resource planning.

Important conclusions include:

(1) Residual emissions from new plants (i.e., emissions from plants that meet current emissions standards) can be important as a percentage of resource cost. Regulatory assessinents of the size of externalities for the new power plants considered here range from 3 to $15 \%$, while abatement cost analyses often yield estimates that are higher than the regulatory determinations as a percentage of resource costs.

(2) Because existing plants are not affected by the National New Source Performance Standards, their air emissions are higher than those of new power plants. The two lowest estimates under consideration yield externality costs for existing plants that are large enough to influence utility dispatch and resource planning decisions substantially.

(3) Direct use of natural gas for heating applications can result in large environmental benefits when compared to use of electric heat, though the exact size of these benefits depends on the type of electricity generation displaced.

(4) Policies that calculate externalities based on a percentage of resource costs submerge important details and should be avoided in the future. Damages from pollutants are not, in general, correlated with resource costs, but are strongly related to pollutant emissions, local topography, population density, and other physical characteristics of the surrounding area.

(5) Emissions that contribute to global warming should be treated equivalently. Carbon, which is the most important contributor to the global warming problem, is by no means the only one. Radiatively active trace gases like methane $\left(\mathrm{CH}_{4}\right)$, nitrous oxide $\left(\mathrm{N}_{2} \mathrm{O}\right)$, and chloroflourocarbons (CFCs) should all be assigned the same externality cost per unit of global warming contribution.

(6) There is an urgent need for a consistent, comprehensive, regional database of emissions factors for new and existing U.S. power plants, as well as for direct combustion. The more common pollutants have well known emissions rates. Others, like $\mathrm{N}_{2} \mathrm{O}$, particulates, and reactive organic gases, are not as well known. A complete treatment rnust include emissions from all stages of energy production and use, for a large number of different technologies and all relevant fuels. 


\section{INTRODUCTION}

Many analysts have attempted to quantify societal costs of pollution and other externalities associated with fossil fuel combustion. A few regulatory bodies have even made first attempts to incorporate externality costs into the resource planning process (Burkhart 1989, Cohen et al. 1990). Unfortunately, estimates of externality costs are often based on quite different assumptions, making comparisons difficult. This paper calculates comparable estimates of external costs for power plants (1989 $\mathrm{c} / \mathrm{kWh}$ ) and direct fuel combustion (1989 $\$ / M M B t u)$, based or, consistent assumptions about heat rates, emissions factors, and resource costs, from ten different analyses and regulatory assessments of the importance of externalities in fossil fuel combustion. This paper makes explicit the effects of various assumptions, illustrates pitfalls in such calculations, and derives lessons for design of policies to incorporate externalities into resource planning.

\section{Organization of Paper}

The next section provides background information about approaches to valuing environmental impacts, and discusses pitfalls in such estimation procedures. Section 3 describes ten different estimates of external costs and Section 4 presents the methodology used to derive consistent estimates. Sections 5 and 6 present and discuss the results, and derive lessons for design of policies to incorporate externalities into resource planning and acquisition.

\section{BACKGROUND}

\section{Framework for Comparison and Scope of the Analysis}

Utilization of of all energy sources generates societal costs that are not reflected in market transactions. Figure 1 (Holdren 1981) shows a detailed listing of stages of energy sources, from exploration to end-use. It also shows phases of each stage, from research to dismantling. A comprehensive analysis of external costs must treat each and every stage in the process, which makes any such calculation inherently difficult.

Figure 2 (Holdren 1981) presents insults, pathways, stresses, and costs. Insults are humankind's physical and chemical intrusions into the natural world. Pathways are those mechanisms by which insults are converted to stresses. Stresses, defined as changes in ambient conditions (social, political, or environmental), then lead directly to societal costs.

Table 1 lists environri,ental and social insults attributable to fossil fuel combustion. To understand how Figure 2 relates to such insults, consider the case of sulfur dioxide. $\mathrm{SO}_{2}$ (the insult) is emitted from oil and coal combustion as a gas (this is the first pathway). Some of the $\mathrm{SO}_{2}$ is converted, through chemical reactions in the atmosphere, to sulfuric acid, some of which then falls in rain into lakes and watersheds (another pathway). Some of this sulfuric acid 
Stages of Energy Sources

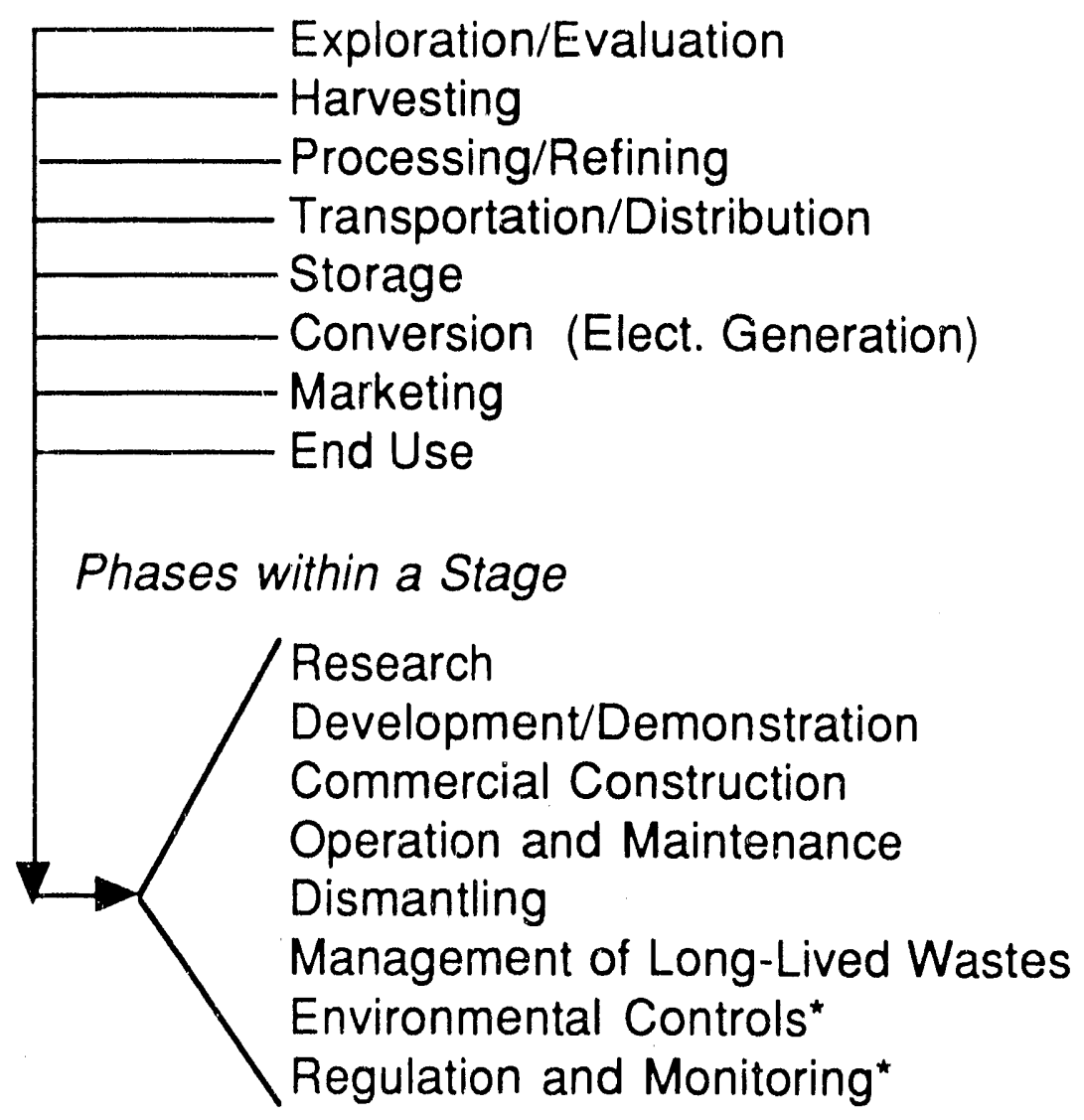

\section{Figure 1: Steps in Energy Production, Processing, and Use}

*Occurs simultaneously with other phases but may have its own effects

Source: Holdren, John P. 1981. "Chapter V. Energy and Human Environment: The Generation and Definition of Environmental Problems." In The European Transiticn from Oil: Societal Impacts and Constraints on Energy Policy. Edited by G. T. Goodman, L. A. Kristoferson and J. M. Hollander. London: Academic Press. 
Insults to Physical and Human Environment

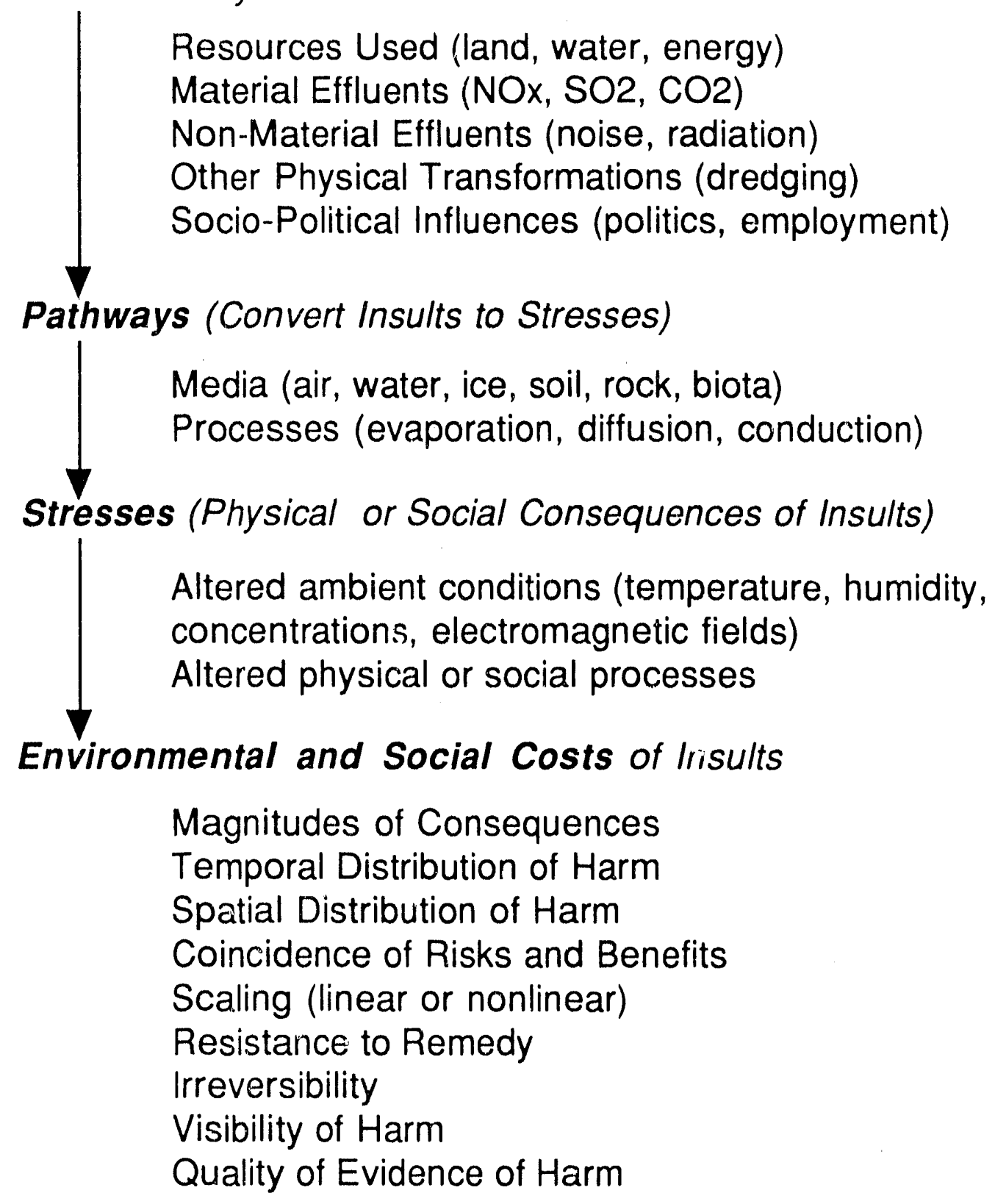

\section{Figure 2: Insults, Pathways, Stresses, and Environmental Costs}

Source: Holdren, John P. 1981. "Chapter V. Energy and Human Environment: The Generation and Definition of Environmental Problems." In The European Transition from Oil: Societal Impacts and Constraints on Energy Policy. Edited by G. T. Goodman, L. A. Kristoferson and J. M. Hollander. London: Academic Press. 
TABLE 1. ENVIRONMENTAL INSULTS FROM FOSSIL FUELS

\begin{tabular}{|c|c|c|c|c|}
\hline & All Fuels & $\begin{array}{l}\text { Natural } \\
\text { Gas }\end{array}$ & Oil & Coal \\
\hline $\begin{array}{l}\text { Exploration/ } \\
\text { Harvesting }\end{array}$ & $\begin{array}{c}\mathrm{CO}_{2}, \mathrm{CH}_{4}, \\
\mathrm{~N}_{2} \mathrm{O}, \mathrm{NO} \times \mathrm{CO}, \\
\mathrm{ROG}, \mathrm{HCs}, \\
\text { particulates, } \\
\text { trace metals, } \\
\text { thermal } \\
\text { pollution } \\
\end{array}$ & $\begin{array}{c}\text { drilling } \\
\text { accidents, } \\
\text { drilling } \\
\text { sludge } \\
\text { disposal }\end{array}$ & $\begin{array}{c}\text { drilling } \\
\text { accidents, } \\
\mathrm{SO}_{2} \text {, drilling } \\
\text { sludge } \\
\text { disposal }\end{array}$ & $\begin{array}{c}\text { mining } \\
\text { injuries, } \\
\text { land } \\
\text { degradation, } \\
\mathrm{SO}_{2}\end{array}$ \\
\hline $\begin{array}{l}\text { Processing/ } \\
\text { Refining }\end{array}$ & $\begin{array}{c}\mathrm{CO}_{2}, \mathrm{CH}_{4}, \\
\mathrm{~N}_{2} \mathrm{O}, \mathrm{NO}_{x}, \mathrm{CO}, \\
\mathrm{ROG}, \mathrm{HCs}, \\
\text { particulates, } \\
\text { trace metals, } \\
\text { thermal } \\
\text { pollution }\end{array}$ & $\begin{array}{l}\text { refinery } \\
\text { accidents, } \\
\text { refinery } \\
\text { waste } \\
\text { disposal }\end{array}$ & $\begin{array}{l}\mathrm{SO}_{2} \text {, refinery } \\
\text { accidents, } \\
\text { refinery } \\
\text { waste } \\
\text { disposal }\end{array}$ & $\mathrm{SO}_{2}$ \\
\hline $\begin{array}{l}\text { Transport/ } \\
\text { Distribution }\end{array}$ & $\begin{array}{c}\mathrm{CO}_{2}, \mathrm{CH}_{4}, \\
\mathrm{~N}_{2} \mathrm{O}, \mathrm{NO}_{x}, \mathrm{CO}, \\
\mathrm{ROG}, \mathrm{HCs}, \\
\text { particulates, } \\
\text { trace metals, } \\
\text { thermal } \\
\text { pollution }\end{array}$ & $\begin{array}{l}\text { pipeline } \\
\text { accidents, } \\
\text { LNG } \\
\text { explosions }\end{array}$ & $\begin{array}{l}\text { pipeline and } \\
\text { tanker } \\
\text { accidents, oil } \\
\text { spills, } \mathrm{SO}_{2}\end{array}$ & $\begin{array}{l}\text { train } \\
\text { accidents, } \\
\mathrm{SO}_{2}\end{array}$ \\
\hline $\begin{array}{l}\text { Conversion/ } \\
\text { Marketing/ } \\
\text { End Use }\end{array}$ & $\begin{array}{c}\mathrm{CO}_{2}, \mathrm{CH}_{4}, \\
\mathrm{~N}_{2} \mathrm{O}, \mathrm{NO}_{x}, \mathrm{CO}, \\
\mathrm{ROG}, \mathrm{HCs}, \\
\text { particulates, } \\
\text { trace metals, } \\
\text { thermal } \\
\text { pollution } \\
\end{array}$ & & $\begin{array}{c}\text { ash disposal, } \\
\mathrm{SO}_{2}\end{array}$ & $\begin{array}{c}\text { ash } \\
\text { disposal, } \\
\mathrm{SO}_{2}\end{array}$ \\
\hline
\end{tabular}

$\mathrm{ROG}=$ Reactive Orgarii; Gases, $\mathrm{HC}=$ hydrocarbons 
is neutralized by buffering chemicals in the water and soil (a third pathway). The altered acidity of the lakes is the stress. The costs (social, economic, and environmental consequences) are the destruction of fish and other wildlife, accumulation of aluminum in plant and animal tissues, damage to trees, and reduction in recreational value of the forest (Harte 1985).

While it is often possible to quantify 'he size of the insult, the pathways may be so numerous or complicated that the)' can only be represented by crude approximations. Even if it is possible to co. ifidently predict stresses from a given insult, translating those stresses into socit tal costs is problematic.

Some U.S. analysts have calculated direct and indirect emissions of $\mathrm{CO}_{2}$ and several other pollutants from fossil fuels (DeLuchi et al. 1987a, DeLuchi et al. 198 'b, Gleick et al. 1989, Meridian Corp. 1989, Unnasch et al. 198y), but none treat all the relevant pollutants for each stage of a large number of technologies. For electric generation technologies, this analysis is restricted to emissions from the point of generation to the point of end-use ${ }^{1}$ (because of a lack of data on emissions factors from various parts of the fuel cycle). Even at these stages, data are lacking for some pollutants. Only emissions per MMBtu of fuel input are included for direct use of natural gas and oil, since the efficiency of the conversion stage for these technologies is not as easy to characterize as for electricity. Analysts may use the estimates for direct combustion presented here with their own assumptions about combustion efficiency to derive the externality cost per MMBtu of delivered heat.

\section{Methods of Calculating External Costs}

According to Griffin and Steele (1986), external costs exist when "the private calculation of benefits or costs differs from society's valuation of benefits or costs". Pollution represents an external cost because damages associated with it are borne by society as a whole and are not reflected in market transactions.

There are two basic approaches to calculating external costs: "direct damage estimation" and "cost of abatement". 2 Direct damage estimation involves calculating damages that can be definitively linked to emissions of a particular pollutant, in dollar terms (Hohmeyer 1988, Ottinger et al. 1990). For instance, Shuman and Cavanagh (Cavanagh et al. 1982) monetize and tally the human health and environmental effects due to coal consumption in new power plants. These effects include premature human deaths, increased health costs, potential famine induced by global warming, and other effects. Direct estimation is extremely difficult, even when there are relatively few pathways.

\footnotetext{
${ }^{1}$ These boundaries include electrical transmission and distribution losses.

2For a more detailed discussion of these two approaches, see Chernick and Caverhill (1989).
} 
Some of the most important effects are impossible to quantify, while others depend on pathways that we do not fully understand.

Cost of abatement approaches typically use the cost of pollution controls imposed by regulatory decisions as a proxy for the true externality costs imposed by a pollutant (Chernick and Caverhill 1989, Marcus 1989). This approach (sometimes called "revealed preferences") assumes that regulators' choices embody society's preferences for pollution control, that the marginal costs of mitigation are known, and that these marginal mitigation costs are incurred solely to reduce emissions of a single pollutant (i.e., that there are no other beneíts to a pollution reduction investment).

If society's preferences are changing rapidly, abatement cost calculations may be misleading, because society's previous preferences for pollution control may not accurately represent its present preferences. If mitigation measures have multiple or incommensurate benefits, revealed preference calculations become difficult. For instance, the cost of an energy conservation measure cannot be Lised to estimate the true value of mitigating $\mathrm{SO}_{2}$ emissions, since the conservation measure avoids power plants, reduces fuel use, and eliminates other pollutants (Krause and Koomey 1989). In contrast the cost of flue-gas desulfurization equipment or the price premium of low-sulfur oil over high-sulfur oil can be used without modification in abatement cost analysis, because the cost of these mitigation measures is incurred solely to reduce sulfur emissions.

\section{Pitfalls in Externality Analysis}

Holdren (1980) identifies pitfalls in calculating total societal costs associated with energy technologies, which affect both direct estimation and cost of abatement approaches. These include: 1) inconsistent boundaries; 2) confusing average and marginal effects; 3 ) illusory precision; 4) envirorimental stochasticity; 5) "confusing things that are countable with things that count".

1) Inconsistent boundaries: boundaries must be drawn consistently to ensure that comparisons between estimates of external costs are fair. This principle implies that the service delivered by competiny resources be identical, that all relevant stages of each resource be included in the comparison, and that geographic boundaries be diawn to include all external effects.

2) Average versus marginal coriparisons: Hohmeyer (1988) calculates costs of externalities from the existing power supply mix in West Geımany. While this calculation is useful to show total societal costs from power production, it will almost certainly be misleading to use these embedded externality costs per $\mathrm{kWh}$ to calculate the cost of externalities from either new 
power plants or from marginal existing capacity, both of which may have characteristics quite different from average existing plants. ${ }^{3}$

3) Illusory precision: there are usually large uncertainties in specifying the size of insults, in translating insults through pathways to stresses, in converting stresses to consequences, and in valuing consequences. To ignore such uncertainty by specifying single point estimates to many significant figures can be quite misleading, since it creates the illusion that the estimates are certain. To avoid misunderstandings, externality cost estimates should be assigned appropriate error bounds. Such uncertainty creates a quandary for regulators, since most regulatory determinations must be in terms of point estimates. Analysts can best serve regulators by making the uncertainties explicit and understandable.

4) Stochasticity: Environmental and social systems are often characterized by stochasticity, or probabilistic variability about some mean value. The most interesting and important interactions between human socielies and the natural world occur when one or both oi these systems are far from their respective mean values. Averaging of important parameters may disguise damages that ocur only under extreme conditions.

For instance, calculations of damages from ambient air pollutant concentrations may yield vastly different results depending on how the concentrations are averaged over time. Damages may not be linearly related to pollutant concentration, and may only occur if concentrations exceed some threshold value. Calculating damages based on the annual average pollutant concentration might be misleading for these reasons. Daily or hourly averages sorted by concentration would give a more accurate picture.

5) "What's countable versus what counts": Analysts often focus on those things that are amenable to quantitative treatment. Yet the probabilities, consequences, and risk-adjusted expected costs of many important external effects (like nuclear sabotage, nuclear proliferation, or global warming) may be difficult or impossible to quantify. To ignore these nonquantifiables may bias the calculations, but to include tham requires difficult value judgements that must be made explicit.

\section{DESCRIPTION OF DIFFERENT ESTIMATES}

In order to illustrate the range of external environmental costs for various power sources, this paper analyzes ten different siudies, regulatory determinations, and proposals concerning these costs. These studies are also summarized in Table 2 and the notes to Table 4.

${ }^{3}$ There are also difficulties in comparing externality costs from Germany to those calculated for the U.S. In spite of these difficulties, I have included Hohmeyer's damage cost estimates for $\mathrm{NO}_{x}$ and $\mathrm{SO}_{2}$ in my calculations, because his work has been widely cited. 
TABLE 2. OVERVIEW OF EXTERNALITY STUDIES

\begin{tabular}{|c|c|c|c|c|}
\hline Study & Insult/Stress & Method & Locale & Reniarks \\
\hline $\begin{array}{l}\text { 1) Shuman and } \\
\text { Cavanagh (Cavanagh et } \\
\text { al.1982) }\end{array}$ & $\begin{array}{l}\text { Human Health, } \\
\text { Prop. Damage, } \\
\text { CO2 -Prop.Dmg, } \\
\text { Famine }\end{array}$ & $\overline{D E}$ & $\begin{array}{l}\text { Northwest } \\
\text { U.S. }\end{array}$ & $\begin{array}{l}\text { Attempt to quantify } \\
\text { difficult damage } \\
\text { effects from global } \\
\text { warming }\end{array}$ \\
\hline 2) EPRI (1987) & $\begin{array}{l}\mathrm{SO}_{2} \\
\mathrm{NO}_{x}\end{array}$ & $\begin{array}{l}\text { DE } \\
\text { DE }\end{array}$ & $\begin{array}{c}\text { Rural PA and } \\
W V ; \text { and } 35 \mathrm{mi} \\
\text { from NYC } \\
\text { NS }\end{array}$ & $\begin{array}{c}\text { My analysis uses } \\
\text { EPRI's mid-range rural } \\
\text { estimate }\end{array}$ \\
\hline 3) Hohmeyer (1988) & $\begin{array}{l}\mathrm{CO}_{2}, \mathrm{NO}_{x}, \mathrm{SO}_{2}, \\
\mathrm{ROG}, \text { Particulates, } \\
\text { subsidios, nuclear } \\
\text { accidents, } \\
\text { depletion }\end{array}$ & $\mathrm{DE}$ & $\begin{array}{l}\text { West } \\
\text { Germany }\end{array}$ & $\begin{array}{l}\text { marginal damage costs } \\
\text { per pound specified in } \\
\text { a personal } \\
\text { communication (1990) }\end{array}$ \\
\hline $\begin{array}{l}\text { 4) Chernick and } \\
\text { Caverhill }(1989)^{*}\end{array}$ & $\begin{array}{l}\text { Particulates, Oil } \\
\text { Imporis } \\
\mathrm{SO}_{2}, \mathrm{NO}_{x} \mathrm{CO}_{2} \\
\mathrm{CH}_{4} \text {, Oil Spills }\end{array}$ & $\begin{array}{c}D E \\
A C+D E\end{array}$ & $\begin{array}{l}\text { New England } \\
\text { New England }\end{array}$ & \\
\hline 5) Schilberg (1989) & $\begin{array}{l}\mathrm{SO}_{2}, \mathrm{NO}_{x}, \mathrm{CO}_{2} \\
\mathrm{ROG}_{1} \mathrm{CH}_{4}, \mathrm{~N}_{2} \mathrm{O}\end{array}$ & $A C$ & $\begin{array}{l}\text { Outside CA, } \\
\text { CA In and } \\
\text { Outside } \\
\text { SCAQMD }\end{array}$ & \\
\hline 6) CEC Staff (1989) & $\begin{array}{l}\mathrm{SO}_{2,} \mathrm{NO}_{x}, \mathrm{CO}_{2} \\
\text { Particulates, } \mathrm{ROG}\end{array}$ & $A C$ & California & $\begin{array}{c}\text { From } 1990 \text { Electricity } \\
\text { Report }\end{array}$ \\
\hline 7) NPPC (1989) & $\begin{array}{l}\text { financial risks from } \\
\text { lack of mudularity }\end{array}$ & RD & $\begin{array}{l}\text { Northwest } \\
\text { U.S. }\end{array}$ & $\begin{array}{l}10 \% \text { adder when } \\
\text { comparing supply } \\
\text { resources to energy } \\
\text { conservation }\end{array}$ \\
\hline 8) NYPSC (1989b) & $\begin{array}{l}\mathrm{SO}_{2}, \mathrm{NO}_{2}, \mathrm{CO}_{2}, \\
\text { Particulates, } \\
\text { Water, Land Use }\end{array}$ & $A C+R D$ & NY State & $\begin{array}{l}\text { Con Ed bidding } \\
\text { system (NY City) }\end{array}$ \\
\hline 9) PSCWI (1989) & All & $\mathrm{RD}$ & V'isconsin & $\begin{array}{c}\text { Noncombustion } \\
\text { credit--cost reduced } \\
\text { by } 15 \% \text { in resource } \\
\text { planning }\end{array}$ \\
\hline 10) NRDC (1989) & $\mathrm{CO}_{2}$ & Other & California & $\begin{array}{l}\text { Proposal-Builds on } \\
\text { NPPC w/variable } \% \\
\text { adders for } \mathrm{CO}_{2}\end{array}$ \\
\hline
\end{tabular}

Method refers to Direct Estimation of Costs $(D E)$, Abatement Costs (AC), or Fiegulatory Determination (RD). NS = not specified. $R O G=$ Reactive Organic Gases.

"Chernick and Caverhill rely most heavily on abatement costs, and the analysis in this paper uses their abatement cost estimates for $\mathrm{SO}_{2}, \mathrm{NO}_{x}$, and $\mathrm{CO}_{2}$. 


\section{Direct Damage Estimation}

Shuman and Cavanagh estimate a range of external costs from coalfired electricity from zero to $20 \mathrm{c} / \mathrm{kWh}$ (in $1980 \$$ ). Their analysis relies on direct estimation of the costs of environmental and human health externalities, including those associated with global warming. They have attempted to capture one cost of global vvarming by estimating the increased probability of millions of famine deaths due to changing climate. They settle on $2 \mathbb{c} / \mathrm{kWh}(1980$ $\$$ ) or about $3.1 \mathrm{c} / \mathrm{kWh}(1989 \$)$ as their best estimate of total external costs associated with new coal-fired electricity generation (Cavanagh et al. 1982).

EFFl (1987) summarizes the direct damage estimates of two studies completed in the mid 1970's. ${ }^{4}$ Oile of these studies gives $\mathrm{SO}_{2}$ damage costs to: rural areas of Western Pennsylvania and West Virginia. The same study entiilates damage costs for sulfur emissions 35 miles from NY City. Both estimates are inciluded in Table 3 for comparisor, thougt, only the rural astimate is used in later calculations. The EPRI best estimate for NOx costs (no location Siven) is more than one order of mannitude smaller (and sometimes two orders of magnitude smaller) than estimnates from most other studies (see Table 3).

Hohmeyer (1588) summarizes direct damage estimates for environmerital and human health externalities from fossil fuel and nuclear electricity generation in West Germany. Hohmeyer's widely cited analysis does not differentiate damage costs by fossil fuel, nor dces it specify the marginal damage cost per mass of pollutant. Hoyever, he supplied the marginal damage costs for non-greenhouse pollutants in a personal communication (1990). Hohmeyer also $c$ jlates externialities associated with depletion of non-renewable resources and public subsidies peculiar to West Germany, which are not included here.

\section{Abatement Cost Approaches}

Chernick and Caverhill (1989) estimate the external costs associated with sulfur dioxide, carbon dioxide, methane, nitrngen oxides, particulates, and oil spills for both electricity and direct fuel consumption in New England, principally relying on abatement cost approaches (their direct damage cost estimates are not used in this paper). They approximate the cost of $\mathrm{CO}_{2}$ emissions using estimates of the cost to seiquester carbon using tree planting. Their analysis is among the most comprehensive yet performed, and their calculations yield externality costs that in some cases exceed the current price of energy.

\footnotetext{
${ }^{4}$ EPRI cites high, low, and mid-range estimates, but only the mid-range estimates are used in later calculations.
} 
TABLE 3. VALUE OF INCREMENTAL EMISSIONS REDUCTIONS (1989\$/LB)

\begin{tabular}{|c|c|c|c|c|c|c|c|}
\hline & $\begin{array}{l}\mathrm{SO}_{2} \\
\$ / l b\end{array}$ & $\begin{array}{l}N O_{x} \\
\$ / 1 b\end{array}$ & $\begin{array}{r}\mathrm{CO}_{2} \\
\$ / \mathrm{lb} \mathrm{C} \\
\end{array}$ & $\begin{array}{l}\text { ROG } \\
\$ \prime \prime b\end{array}$ & $\begin{array}{l}\mathrm{CH}_{4} \\
\$ / \mathrm{lb}\end{array}$ & $\begin{array}{l}\mathrm{N}_{2} \mathrm{C} \\
\$ / \mathrm{lb}\end{array}$ & $\begin{array}{l}\text { Particulates } \\
\$ / 1 \mathrm{~b}\end{array}$ \\
\hline \multicolumn{8}{|l|}{ EPRI (1987) rural PA, WV } \\
\hline Low & 0.21 & 0.02 & - & - & - & - & - \\
\hline High & 0.85 & 0.23 & - & - & - & - & - \\
\hline Best Estimate & 0.48 & 0.07 & - & - & - & - & - \\
\hline \multicolumn{8}{|l|}{ EPRI (1987) (Sub)urban" } \\
\hline Low & 0.48 & 0.02 & - & - & - & - & - \\
\hline High & 2.31 & 0.23 & - & - & - & - & - \\
\hline Best Estimate & 1.27 & 0.07 & - & - & - & - & - \\
\hline \multicolumn{8}{|l|}{ Hohineyer (1988) } \\
\hline Low & 0.233 & 0.292 & 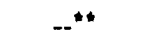 & 0.233 & - & - & 0.233 \\
\hline High & 1.244 & 1.555 & $-{ }^{* *}$ & 1.2 .14 & - & - & 1.244 \\
\hline Chernick et al. (1989) & 0.92 & 1.58 & 0.042 & - & 0.37 & - & $>2.63$ \\
\hline \multicolumn{8}{|l|}{ Schilberg et al. (1989) } \\
\hline Outside CA & 0.50 & 1.35 & 0.027 & 0.33 & 0.19 & 1.85 & - \\
\hline CA Outside SCAQMD & 0.90 & 9.40 & 0.027 & 0.57 & 0.19 & 1.85 & - \\
\hline CA Inside SCAQMD & 9.15 & 12.25 & 0.027 & 8.75 & 0.19 & 1.85 & - \\
\hline CEC Staff (1989) in CA & 5.75 & 5.80 & 0.013 & 1.65 & - & - & 3.9 \\
\hline Implied by NYPSC(1989b) & 0.48 & 0.94 & 0.0015 & - & - & - & 1.01 \\
\hline
\end{tabular}

Comments: NYPSC numbers were derived from the Con Ed/NYPSC worksheet (see Appendix B). The weighted point value of a particular pollutant $a$, a percentage of total points was multiplied by $1.405 \% / \mathrm{kWh}$, and divided by the required change in emissions needed to yield all the points for the pollutant. Particulate matter estimates (PM) of CEC are for all particulates less than 10 microns in diameter, while the Con Ed/NYPSC system and Chernick et al. do not distinguish particulates by size. $R O G=$ Reactive Organic Gases

- Suburban/urban location is 35 miles $(56 \mathrm{~km})$ outside of NY City. Only sulfur dioxide damages are estimated for this location. Nitrogen oxide damages were only assigned one number by EPRI, so this number is used for both the rural and suburban/urban estimates.

"Hohmeyer does estimate total external costs for global climate change, but the $\$ /$ ib numbers for $\mathrm{CO}_{2}$ and other greenhouse gases were not available in time for publication. 
$\therefore$ ir quality problems in California have led the regulatory agencies in this state to take a leading role in quantifying the social cost of air pollution (Cohen et al. 199'3). The California Energy Commission (CEC) Staff, in the context of the planning process for the CEC's 1990 Electricity Report (ER-90), use an abatement cost analysis to estimate the value of air emissions reductions of $\mathrm{SO}_{2}, \mathrm{NO}_{x} \mathrm{CO}_{2}, \mathrm{ROG}$, and particulates smaller than 10 microns, using data from the Southern California Edison territory and the South Coast Air Bizsin in LA. I assumed that the values calculated by the CEC staff were in 1989 ${ }^{\circ}$ (CEC Staff i yo9). Schilberg et al. (1989), who are intervenors in the ER-90 process, use an abatement cost approach to derive the external cost of $\mathrm{SO}_{2}, \mathrm{NO}_{x}, \mathrm{CO}_{2}$, Reactive Organic Gases (ROG), $\mathrm{CH}_{4}$, and $\mathrm{N}_{2} \mathrm{O}$ for the U.S. outside of California, tor California outside of the South Coast Air Quality Management District (SCAQMD), and for California inside SCAQMD. Schilberg et al.'s estimates are in $1989 \$$.

\section{Regulatory Determinations}

The act establishing the Northwest Power Planning Council (NPPC) requires consideration of envirnnmental impacts in regional least-cost planning (Cohen et al. 1990). NPPC has since 1980 encouraged utilities in its region to give conservation a $10 \%$ cost advantage over conventional supply resources, because of lower financial risks associated with modular resources. If avoided costs (based on a proxy fossil iuel unit) are $5 \mathrm{c} / \mathrm{kWh}$, all conservation measures thiat cost less than $5.5 \notin / \mathrm{kWh}(5 \notin \times 1.1)$ are considered economic (NPPC 1989). The Col .ncil does not currently advocate use of the 10\% "adder" to differentiate between supply resources, although I have included it here to show the implications uf using a single percentage adder for this purpose. ${ }^{5}$

New York State's Public Service Cummission (NYPSC) has required the State's investor-owned utilities to include a "point" system for calculating environmental costs of competing supply and demand resources as part of their integrated resources bidding programs. This scheme assigns point values to different levels of air, water, and land use. The most environmentally disruptive new resource (coal), under the most unfavorable circumstances, will be assigned an environmental cost of $1.405 \$ / \mathrm{kWh}$. All other resources are assigned some fraction of that total, depending on their point score. Energy efficiency, since it avoids all the external costs analyzed, would have no externality charge attached to it. The adjusted bids are then used to determine the lowest bidder (NYPSC 1989a). To iliustrate this approach, this paper

\footnotetext{
5 The Vermont Public Service Board, in April 1990, instituted a 10\% comparative risk and flexibility adder (similar 10 the NPPC adder) and a $5 \%$ environmental externality adder, both for use in comparing energy conservation to avoided costs of supply technologies in the resource planning process. (VTPSB 1990).
} 
analyzes the environmental component of Consolidated Edison Company of New York's bidding system (NYPSC 1989b). ${ }^{6}$

In 1989, the Public Service Commission of Wisconsin (PSCWI) implemented a "non-combustion credit" of 15\% for non-fossil supply and demand-side resources (excluding nuclear power, which is restricted by law in Wisconsin). In this case, the cost of conservation and renewables is reduced by $15 \%$, so that a conservation measure costing $\$ 100 / \mathrm{kW}$ is treated as if it cost $\$ 85 / \mathrm{kW}$ for purposes of determining cosi effectiven ess in Wisconsin's resource planning process (PSCWI 1989). This policy is equivalent to increasing the cost of conventional resources by $17.6 \%$.

\section{Other}

The Natural Resources Defense Council (NRDC) in the context of Califorrila's collaborative process, has proposed a variable percentage "adder" to account for $\mathrm{CO}_{2}$ (NRDC 1989) that builds upon NPPC's $10 \%$ cost adder. All supply resources would be increased in cost by $10 \%$, plus an additional $15 \%$ for $\mathrm{CO}_{2}$ emissions equal to that of a coal jlant, $12 \%$ for that from an oil plant, and $9 \%$ from natural gas. For direct natural gas conservation measures, NRDC proposes that the $9 \%$ adder be used alone (and presurnably direct oil use would be treated similarly, using a $12 \%$ adder). This proposal does not currently account for differential heat rates of power plants. It is included here to show the consequences of a modified "adder" to calculate external costs.

\section{METHODOLOGY}

The analysis in this paper uses various estimates of external costs, in conjunction with consistent assumptions about emissions factors, heat rates, and resource costs, to arrive at comparable estimates in $1989 \notin / \mathrm{kWh}$ or $1989 \$$ MMBtu (see Appendix A for a summary of those assumptions). Wherever possible, externality costs (in $₫ / \mathrm{kWh}$ ) were calculated using Equation 2 (below) or its equivalent for direct fuel consumption.

\section{Calculating Externality Costs}

In general, external costs can be crudely characterized by Equation 1:

$$
\text { Externality Cost }=\text { Size of Insult } \times\left(\frac{\text { Damage Cost }}{\text { unit of insult }}\right)
$$

where

Externality Cost $=$ total external cost to society, in dollars;

\footnotetext{
6 The environmental component of the NY State bidding system does not vary much by utility service territory, so choosing the urban territory of Con Ed will yield results that are representative for most of NY.
} 
Size of Insult is expressed in physical units (lbs emitted or hectares degraded); and

Damage Cost is expressed in dollars per physical unit of insult.

Externality costs must be normalized to some common unit of service for consistent comparison. This unit is delivered $\mathrm{kWh}$, which includes transmission and distribution losses. For direct fuel consumption, the unit of service is MMBtu.

Air pollution and climate effects tend to dominate most analyses of fossil fuel externalities, and they are the principal focus of this paper. Such external costs, which vary with power plant fuel consumption, can be characterized by Equation 2 (which is a variation of Equation 1):

Externality Cost $\left(\frac{\vec{\psi}}{k w h}\right)=E F\left(\frac{\mathrm{lbs}}{\mathrm{Btu}}\right) \times H R\left(\frac{\mathrm{Btu}}{\mathrm{kwh}}\right) \times \operatorname{MDC}\left(\frac{\Phi}{\mathrm{lb}}\right)$

where

$E F=$ Emission Factor, in Ibs/Btu of fuel consumed;

$H R=$ Heat Rate of power plant, in Btus/kWh; ${ }^{7}$ and

$M D C=$ Marginal Damage Cost, in $₫ / / b$.

The emission factor relates the particular insult to the amount of fuel burned (Táble A.1 in Appendix A shows these factors). The heat rate characterizes the first pathway by which the insult is converted from its fuelrelated state to a form that impinges upon the natural environment. The marginal damage cost relates the insult to the social costs. It embodies a relationship between the insult and the stresses that depends on assumptions about geography, dose response, weather, biotic interactions, population density, post-combustion pathways, and myriad other factors.

EF and HR are physical parameters that can be measured, while MDC can be calculated using direct cost estimation, abatement costs, or some combination of both. MDC is an important parameter for regulatory policy analysis, but it is usually difficult to calculate and may sometimes be unquantifiable in principle. It should always be stated explicitly, along with the large number of assumptions needed to calculate such a value.

\section{Marginal Damage Costs}

Table 3 shows the marginal damage cost (or the value of incremental emissions reductions) from five externality studies and one regulatory

\footnotetext{
${ }^{7}$ For direct fuel use, this term becomes the inverse of combustion efficiency.
} 
determination (in $\$ / \mathrm{lb}$ of pollutarit). The assumptions about value of pollution reductions for the other studies summarized in Table 2 cannot easily be derived because they treat many pollutants in the aggregate. The implied value of emissions reductions for the Consolidated Edison Company's bidding system have been derived using the method described in Appendix B.

The difference in assessments of pollutant value reflect different geographic and environmental circumstances, as well as other factors. The assessments of the value of NOx reductions in California are substantially higher than those estimated by Chernick for New England and implied by the NYPSC's bidding system. California has snme of the strictest air pollution controls in the nation, which reflect its se'vere $\mathrm{NO}_{x}$-related ozone problems.

Chernick's, Schilberg's, and the CEC's estimates of the value of $\mathrm{CO}_{2}$ reductions are based on proxy approaches, while the value implied in the Con Ed/NYPSC system (which is less than twelve percent of the other estimates) is based on cautious initial regulatory response to the global warming problem, and not on explicit analysis.

Consistent emissions estimates for pollutants other than $\mathrm{NO}_{x}, \mathrm{SO}_{2}$, and $\mathrm{CO}_{2}$, (such as particulates, reactive organic gases, $\mathrm{N}_{2} \mathrm{O}$, and methane) were not available, so the external costs related to these pollutants were not included in the calculations. As Table 3 shows, estimates for some of these pollutants indicate that they can be more costly to society per unit mass than the three that have been included in the calculations (e.g., particulates). Of course, the damages per $\mathrm{kWh}$ depend upon the respective emission factors for each polluiant.

\section{RESULTS}

\section{New Power Plants}

Table 4 shows externalities from new power plants that meet the National New Source Performance Standards (NSPS). in general, natural gas has lower external costs than other fuels used in comparable power plants. Oil is more damaging than gas but less damaging than coal, accordirig to these estimates. This conclusion is the result of the emissions factors in Table A.1 (in Appendix A), which are lowest for gas and next lowest for oil, for all three pollutants. This ranking also seems to be reflected in the various regulatory estimates of these externalities, although for systems based on a percentage of resource cost (such as NPPC, PSCWI, and NRDC), this result is coincider:tal. Table 5 shows estimates of total external costs by technology type, as a percentage of delivered cost.

In absolute terms, the lowest estimate for external costs of NSPS gas plants (EPRI) yields negligible $\mathrm{NO}_{x}$ and $\mathrm{SO}_{2}$ costs. EPRI assigns oil combinedcycle plants and coal plants $\mathrm{NO}_{x}$ plus $\mathrm{SO}_{2}$ costs of $0.10 \varnothing / \mathrm{kWh}$ and $0.34 \varnothing / \mathrm{kWh}$, respectively. All other analyses and regulatory determinations that treat such costs explicitly (except for Hohmeyer's low estimate) yield damage costs for 
TABLE 4. EXTERNALITIES FROM NEW NSPS POWER PLANTS (1989 \&/kWh)

\begin{tabular}{|c|c|c|c|c|c|c|}
\hline & & $\begin{array}{l}\text { CC } \\
\text { Gas }\end{array}$ & $\begin{array}{l}\text { CT } \\
\text { Gas }\end{array}$ & $\begin{array}{l}\text { CC } \\
\text { OII }\end{array}$ & $\begin{array}{l}\text { CT } \\
\text { OII }\end{array}$ & $\begin{array}{c}\text { Coal } \\
\text { Steam }\end{array}$ \\
\hline Heat Rate (Btus/kWh) & & 8440 & 13900 & 8440 & 13900 & 9660 \\
\hline HR+T\&D losses (Btus/kWh) & & 8946 & 14734 & 8946 & 14734 & 10240 \\
\hline Delivered Cost ( $₫ / k W h)$ & & 5.5 & 13.8 & 6.0 & 14.6 & 8.3 \\
\hline \multirow{6}{*}{$\begin{array}{l}\text { 1) Shuman and Cavanagh } \\
\text { (Cavanagh et al. 1982) }\end{array}$} & Human Health & & & & & 1.22 \\
\hline & Prop. Damage & & & & & 0.02 \\
\hline & $\mathrm{CO}_{2}$-Prop. Dmg & & & & & 0.01 \\
\hline & $\mathrm{CO}_{2}$-Famine & & & & & 1.87 \\
\hline & Best Estimate & & & & & 3.12 \\
\hline & Range & & & & & $0.045-32$ \\
\hline \multirow[t]{4}{*}{ 2) EPRI (1987) } & $\mathrm{SO}_{2}$ & 0 & 0 & 0.09 & 0.14 & 0.30 \\
\hline & $\mathrm{NO}^{X}$ & 0.012 & 0.020 & 0.01 & 0.02 & 0.04 \\
\hline & $\mathrm{SO}_{2}+\mathrm{NO}_{x}$ & 0.012 & 0.020 & 0.10 & 0.16 & 0.34 \\
\hline & Range & $\begin{array}{l}0.004- \\
0.041\end{array}$ & $\begin{array}{l}0.006- \\
0.068\end{array}$ & $\begin{array}{l}0.04- \\
0.19\end{array}$ & $\begin{array}{l}0.07- \\
0.32\end{array}$ & $0.14-0.67$ \\
\hline \multirow[t]{6}{*}{ 3) Hohmeyer (1988) Low } & $\mathrm{SO}_{2}$ & 0.00 & 0.00 & 0.04 & 0.07 & 0.14 \\
\hline & $\mathrm{NO}_{x}$ & 0.05 & 0.09 & 0.05 & 0.09 & 0.18 \\
\hline & $\mathrm{SO}_{2}+\mathrm{NO}_{x}$ & 0.05 & 0.09 & 0.09 & 0.15 & 0.32 \\
\hline & $\mathrm{SO}_{2}$ & 0.00 & 0.00 & 0.22 & 0.37 & 0.76 \\
\hline & $N_{x}$ & 0.28 & 0.46 & 0.28 & 0.46 & 0.96 \\
\hline & $\mathrm{SO}_{2}+\mathrm{NO}_{x}$ & 0.28 & 0.46 & 0.50 & 0.82 & 1.72 \\
\hline \multirow[t]{4}{*}{ 4) Chernick (1989) } & $\mathrm{SO}_{2}$ & 0.00 & 0.00 & 0.16 & 0.27 & 0.56 \\
\hline & $\mathrm{NO}_{x}$ & 0.28 & 0.46 & 0.28 & 0.46 & 0.97 \\
\hline & $\mathrm{CO}_{2}$ & 1.13 & 1.86 & 1.73 & 2.72 & 2.45 \\
\hline & Total & 1.41 & 2.32 & 2.17 & 3.46 & 3.98 \\
\hline 5) Schilberg (1989) & $\mathrm{SO}_{2}$ & 0.00 & 0.00 & 0.09 & 0.15 & 0.31 \\
\hline \multirow[t]{3}{*}{ Outside CA } & $\mathrm{NO}_{x}$ & 0.24 & 0.40 & 0.24 & 0.40 & 0.83 \\
\hline & $\mathrm{CO}_{2}$ & 0.72 & 1.19 & 1.11 & 1.75 & 1.58 \\
\hline & Total & 0.97 & 1.59 & 1.44 & 2.30 & 2.71 \\
\hline \multirow[t]{4}{*}{ CA Outside SCAQMD } & $\mathrm{SO}_{2}$ & 0.00 & 0.00 & 0.16 & 0.27 & 0.55 \\
\hline & $\mathrm{NO}_{x}$ & 1.68 & 2.77 & 1.68 & 2.77 & 5.78 \\
\hline & $\mathrm{CO}_{2}$ & 0.72 & 1.19 & 1.11 & 1.75 & 1.58 \\
\hline & Total & 2.41 & 3.96 & 2.95 & 4.79 & 7.90 \\
\hline \multirow[t]{4}{*}{ CA Inside SCAQMD } & $\mathrm{SO}_{2}$ & 0.00 & 0.0 & 1.64 & 2.70 & 5.62 \\
\hline & $\mathrm{NO}_{x}$ & 2.19 & 3.61 & 2.19 & 3.61 & 7.53 \\
\hline & $\mathrm{CO}_{2}$ & 0.72 & 1.19 & 1.11 & 1.75 & 1.58 \\
\hline & Total & 2.92 & 4.80 & 4.94 & 8.06 & 14.72 \\
\hline
\end{tabular}


TABLE 4 (continued). EXTERNALITIES FROM NEW NSPS POWER PLANTS (1989 $\mathbf{c} / \mathrm{kWh})$

\begin{tabular}{|c|c|c|c|c|c|c|}
\hline & & $\begin{array}{l}\text { CC } \\
\text { Gas }\end{array}$ & $\begin{array}{l}\text { CT } \\
\text { Gas }\end{array}$ & $\begin{array}{l}\mathrm{CC} \\
\text { OII }\end{array}$ & $\begin{array}{l}\overline{C T} \\
\text { OII }\end{array}$ & $\begin{array}{l}\text { Coal } \\
\text { Steam }\end{array}$ \\
\hline Heat Rate (Btus/kWh) & & 8440 & 13900 & 8440 & 13900 & 9660 \\
\hline HR+T\&D (Btus/kWh) & & 8946 & 14734 & 8946 & 14734 & 10240 \\
\hline Delivered Cost ( $₫ / k W h)$ & & 5.5 & 13.8 & 6.0 & 14.6 & 8.3 \\
\hline \multirow[t]{4}{*}{ 6) CEC Staft (CEC 1989) } & $\mathrm{SO}_{2}$ & 0.00 & 0.00 & 1.03 & 1.69 & 3.53 \\
\hline & $\mathrm{NO}_{x}$ & 1.04 & 1.11 & 1.04 & 1.71 & 3.56 \\
\hline & $\mathrm{CO}_{2}$ & 0.35 & 0.57 & 0.53 & 0.84 & 0.76 \\
\hline & Total & 1.39 & 1.69 & 2.60 & 4.25 & 7.85 \\
\hline 7) NPPC (1989) & All but $\mathrm{CO}_{2}$ & 0.55 & 1.38 & 0.60 & 1.46 & 0.83 \\
\hline 8) Con Ed/NY State & $\mathrm{SO}_{2}$ & 0.00 & 0.00 & 0.11 & 0.16 & 0.26 \\
\hline Bidding System & $\mathrm{NO}_{x}$ & 0.22 & 0.22 & 0.22 & 0.33 & 0.56 \\
\hline \multirow[t]{5}{*}{ (NYPSC 1989b) } & $\mathrm{CO}_{2}$ & 0.04 & 0.06 & 0.06 & 0.06 & 0.06 \\
\hline & Particulates & 0.01 & 0.01 & 0.01 & 0.01 & 0.02 \\
\hline & Water & 0.07 & 0.00 & 0.07 & 0.00 & 0.08 \\
\hline & Land Use & 0.17 & 0.17 & 0.20 & 0.20 & 0.29 \\
\hline & All & 0.50 & 0.46 & 0.67 & 0.76 & 1.27 \\
\hline \multirow[t]{2}{*}{ 9) PSCWI (1989) } & $C C E=0.5 \times D C$ & 0.41 & 1.04 & 0.45 & 1.10 & 0.62 \\
\hline & $C C E=D C$ & 0.83 & 2.07 & 0.90 & 2.19 & 1.25 \\
\hline 10) NRDC (1989) & $\mathrm{CO}_{2}$ & 0.50 & 1.24 & 0.72 & 1.75 & 1.25 \\
\hline NRDC Total & All & 1.05 & 2.62 & 1.32 & 3.21 & 2.08 \\
\hline
\end{tabular}

General: $₫ / \mathrm{kWh}$ numbers for estimates 1-6 have been calculated using the heat rates at the top of this table, using the appropriate New Source Performance Standards (NSPS) emissions factors for each power plant (Table A.2), but varying the value assigned to each $\mathrm{lb}$ of emissions using the assumptions of various analysts and regulatory bodies (Table 3). All EPRI power plants meet the NSPS. Fuel prices are based on levelized forecasts for 1988-2000 from the DOE's Annual Energy Outlook (USDOE 1989t). Discount rate is $6.1 \%$ real. Nominal Fixed Charge Rate $=16.8 \%$ for $30 \mathrm{yr}$ lifetime, $15.4 \%$ for 40 year life (coal only). Transmission and Distribution losses $=6 \%$. Assumed reserve margin requirement is $20 \%$, which is used to calculate delivered costs of generation. Oil Combustion Turbine (CT) uses $0.3 \%$ S Distillate Oil; Combined Cycle (CC) Oil uses $1 \% \mathrm{~S}$ Residual Oil; Coal Steam Plant is a supercritical unit that uses $1.2 \%$ S Coal with a heat content of 10,460 Btus/lb (which is average for coal in US utilities in 1988--See USDOE (1989c)). $\mathrm{CCE}=$ Cost of Conserved Energy; $\mathrm{DC}=$ Delivered cost of electricity from supply resources (from Table A.3)

1) Shuman and Cavanagh's analysis relies on direct estimation of the dollar value of human health and environmental externalities. The estimates have been adjusted from $1980 \$$ to $1989 \$$ using the Consumer Price Index 1980-88, and assuming 5\% inflation for 1988-89. The best estimates are equal to $10 \%$ of the high values.

2) The EPRI Technical Assessment Guide, v.4 (1987) quotes the results of two direct cost estimation studies, one for $\mathrm{SO}_{2}$ and one for $\mathrm{NO}_{x}$ in $1975 \$$. These costs were adjusted to $1989 \$$ using the consumer price index. 


\section{TABLE 4 NOTES (continued). EXTERNALITIES FROM NEW NSFS POWER}

PLANTS (1989 $/ \mathrm{kWh})$

3) Hohmeyer derives estimates of external costs from studies of the direct human health and environmental damages from nuclear and fossil fuels. He reports snly total damages and does not explicitly differentiate between the fossil fuels or pollutants in his widely circulated book, but he reported marginal damage costs for each pollutant in a personal communication it tohmeyer 1990). The estimates have been converted from 1982 to 1989 Deutschmarks using a $1.8 \%$ annual inflaiion rate, and to U.S. dollars using an exchange rate of 2 DM/U.S. \$.

4) Chemick and Caverhill's estimates are based principally on abatement costs, but also undertake direct cost estimation for some pollutants. They explicitly show their assumptions about marginal damage costs in dollars per pound of pollutant, which are in $1988 \$$ and have been converted to $1989 \$$ using $5 \%$ inflation.

5) Schilberg's estimates of the damage cost per lb of pollutant are based on abatement cost analysis. I assume that they are given in $1989 \$$.

6) The California Energy Commission (CEC) Staff calculated the value of air emissions reductions in dollars per ton of pollutant using abatement cost data from the Southern California Edison territory and the South Coast Air Basin in LA. I assumed that these values were in $1989 \$$.

7) The Northwest Power Planning Courcil (NPPC) encourages utilities in their region to increase the cost of supply resources by $10 \%$ when calculating the cost effectiveness of conservation. The Council does not currently advocate using the $10 \%$ "adder" to differentiate between supply resources, but the adder is included here to show the effects of using a single percentage adder for that purpose.

8) Consolidated Edison Company, as required by the New York State Public Service Commission (NYPSC), has established a point system for calculating environmental costs of competing new supply and demand resources. This scheme assigns point values to different levels of air, water, and land use. The most environmentally disruptive resource, under the most unfavorable circumstances, will be assigned an environmental cost of $1.405 \mathrm{c} / \mathrm{kWh}$. All other resources are assigned some fraction of that total, depending on their point score. I calculated point scores for each resource based on a worksheet supplied in NYPSC documents, assuming that the externality costs were already in 1989\$. Appendix B presents details of the point system and my assumptions.

9) The Public Service Commission of Wisconsin (PSCWI) reduces the cost of demand-side management options by $15 \%$ to account for external costs in their resource planning process. I calculated implied external costs for conservation equal in cost $1050 \%$ and $100 \%$ of the competing supply resource.

10) The Natural Resources Defense Council (NRDC), in the context of the California Collaborative Process, proposed a variable percentage "adder" to account for $\mathrm{CO}_{2}$. All supply resources would be increased in cost by $10 \%$, plus an additional $15 \%$ for $\mathrm{CO}_{2}$ emissions equal to that of a coal plant, $12 \%$ for that from an oil plant, and $9 \%$ from natural gas. For direct natural gas conservation measures, INRDC proposes that the $9 \%$ adder be used alone (and presumably proposes that a $12 \%$ adder be used for direct oil use). 
TABLE 5. EXTERNALITIES FROM NEW NSPS POWER PLANTS (TOTAL AS \% OF DELIVERED COST)

\begin{tabular}{|c|c|c|c|c|c|}
\hline 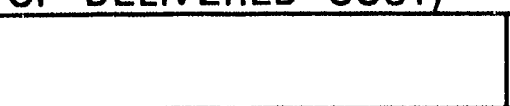 & $\begin{array}{l}\text { CC } \\
\text { Gas }\end{array}$ & $\begin{array}{l}\text { CT } \\
\text { Gas }\end{array}$ & $\begin{array}{l}\mathrm{CC} \\
\text { OII }\end{array}$ & $\begin{array}{l}\text { CT } \\
\text { OII }\end{array}$ & $\widehat{\text { Coal }}$ \\
\hline Delivered Cost ( 89 c/kWh) & 5.5 & 13.8 & 6.0 & 14.6 & 8.3 \\
\hline $\begin{array}{l}\text { 1) Shuman and Cavanägh } \\
\text { (Cavanagh 1982) }\end{array}$ & & & & & $37 \%$ \\
\hline 2) EPRI (1987): $\mathrm{SO}_{2}+\mathrm{NO}_{x}$ & $0.2 \%$ & $0.1 \%$ & $1.7 \%$ & $1.1 \%$ & $4.1 \%$ \\
\hline 3)Hohmeyer (1988) & & & & & \\
\hline $\mathrm{SO}_{2}+\mathrm{NO}_{x}-$ Low & $0.9 \%$ & $0.6 \%$ & $1.6 \%$ & $1.1 \%$ & $3.9 \%$ \\
\hline $\mathrm{SO}_{2}+\mathrm{NC}_{x}-\mathrm{High}$ & $5.0 \%$ & $3.3 \%$ & $8.3 \%$ & $5.6 \%$ & $20.7 \%$ \\
\hline 4) Chernick et al(198S) & $26 \%$ & $17 \%$ & $36 \%$ & $24 \%$ & $48 \%$ \\
\hline 5) Schilverg et al (1989) & & & & & \\
\hline Outsicie CA & $17 \%$ & $12 \%$ & $24 \%$ & $10 \%$ & $33 \%$ \\
\hline CA Outside SCAQMD & $44 \%$ & $29 \%$ & $49 \%$ & $33 \%$ & $95 \%$ \\
\hline CA Inside SCAQMD & $53 \%$ & $35 \%$ & $82 \%$ & $55 \%$ & $177 \%$ \\
\hline 6) CEC Staff (CEC 1989) & $25 \%$ & $12 \%$ & $43 \%$ & $29 \%$ & $94 \%$ \\
\hline 7) NPPC (1989) & $10 \%$ & $10 \%$ & $10 \%$ & $10 \%$ & $10 \%$ \\
\hline 8) PSCWI (1989) & $15 \%$ & $15 \%$ & $15 \%$ & $15 \%$ & $15 \%$ \\
\hline $\begin{array}{l}\text { 9) NY State Bidding Systems } \\
\text { (NYPSC 1989b) }\end{array}$ & $9 \%$ & $3 \%$ & $11 \%$ & $5 \%$ & $15 \%$ \\
\hline 10) NRDC (1989) & $19 \%$ & $19 \%$ & $22 \%$ & $22 \%$ & $25 \%$ \\
\hline
\end{tabular}

This table expresses the totals calculated in Table 4 as a \% of delivered cost of supply resources; Calculation for EPRI and Shuman and Cavanagh uses their best estimates. Calculation for PSCWI uses the case where Cost of Conserved Energy equals Delivered Cost. When externality costs are expressed as a \% of the cost of a power plant, the delivered costs in Table A.3 (derived from EPRI (1986)) including 6\% T\&D losses were used. 
these two pollutants that are more than a factor of two higher than EPRI's costs. in all cases where it is explicitly included (except for the NYPSC's bidding system), $\mathrm{CO}_{2}$ adds more than $0.3 \% / \mathrm{kWh}$ in societal costs.

Regulatory determinations range from 3 to $15 \%$ of resource cost, depending upon the technology, while estimates of external costs from abetement cost or direct damage analyses are often larger than the regulatory determinations as a percentage of resource costs. These results indicate that externality costs can be significant fractions of the delivered cost of new electricity resources. Because many externalities were excluded from the analysis, this conclusion seems robust.

\section{Existing Power Plants}

I have included results for existing power plants to show the disparities in emissions factors between new and existing plants. These disparities can be important if the operating hours of old plants can be curtailed or the plants can be retired altogether when new supn!y or demand-side resources are added. The heat rates are derived from NERC (1989) and LiDOE (1989c). The USDOE's emissions estimates are oniy for steam power plants (USDOE 1989a), which generate about $99 \%$ of the fossil-fired $\mathrm{kWh}$ in the U.S. Plant by plant analysis would be necessary to analyze emissions in a particular utility system. However, the results presented here give a rough indication of enrissions from existing steam-electric plants by fuel type.

Table 6 shows the external costs for average existing gas-steam, oilsteam and coal-steam power plants implied by the value of emission reductions in Table 3 and the emissions factors in Table A.1. Table 7 shows these estimates as a percentage of the 1988 electricity price.

Because existing plants in the U.S. are not affected by the National New Source Performance Standards, their air emissions are higher than those of new power plants. EPRI's best estimates of just $\mathrm{SO}_{2}$ plus $\mathrm{NO}$ yield negligible external costs for existing gas plants (the result of the low $\mathrm{NO}_{\mathrm{X}}$ costs) and costs of $0.55 \notin / \mathrm{kWh}$ for oil and $1.1 \mathrm{\phi} / \mathrm{kWh}$ for coal. The values implied by the Con Edison/NYPSC bidding system yield estimates of about $1.9 \phi / \mathrm{kWh}$ for coal, $0.96 \notin / \mathrm{kWh}$ for oil, and $0.43 \notin / \mathrm{kWh}$ for natural gas power plants. These estimates are about $29 \%, 14 \%$, and $6 \%$, respectively, of the 1988 U.S. electricity price of $6.6 \$ / \mathrm{kWh}(1989 \$)$, and only include external costs from emission of $\mathrm{SO}_{2}, \mathrm{NO}_{x}$, and $\mathrm{CO}_{2}$. They ignore particulates and water/land use effects, as well as other externalities.

The two lowest estimates under consideration 8 therefore yield externality costs for existing plants that are large enough t/) influence utility dispatch and

\footnotetext{
${ }^{8}$ Hohmeyer's low estimate yields smaller external costs than the EPRI best estimate, but this is not a consistent comparison.
} 
TABLE ô. EXTERNAL COSTS FROM EXISTING U.S. STEAM POWER PLANTS IN $1988(1989 \mathrm{C} / \mathrm{KWH})$

\begin{tabular}{|c|c|c|c|c|}
\hline & & Gas & Oil & Coal \\
\hline 1988 Heat Rates (Btus $/ \mathrm{kWh}$ ) & & 10342 & 10910 & 10254 \\
\hline HR + T\&D losses (Btus/kWh) & & 10962 & 11565 & 10869 \\
\hline 1988 U.S. Electricity Price ( $₫ / k W h)$ & & 6.6 & 6.6 & 6.6 \\
\hline \multirow[t]{3}{*}{ EPRI (1987) } & $\mathrm{SO}_{2}$ & 0.00 & 0.53 & 1.05 \\
\hline & $\mathrm{NO}_{x}$ & 0.03 & 0.03 & 0.06 \\
\hline & $\mathrm{SO}_{2}+\mathrm{NO}_{x}$ & 0.03 & 0.55 & 1.11 \\
\hline \multirow[t]{6}{*}{ Hohmeyer (1988) } & $\mathrm{SO}_{2}$ & 0.00 & 0.25 & 0.51 \\
\hline & $\mathrm{NO}_{x}$ & 0.12 & 0.11 & 0.25 \\
\hline & $\mathrm{SO}_{2}+\mathrm{NO}_{x}$ & 0.12 & 0.37 & 0.75 \\
\hline & $\mathrm{SO}_{2}$ & 0.00 & 1.36 & 2.70 \\
\hline & $\mathrm{NO}_{x}$ & 0.63 & 0.59 & 1.31 \\
\hline & $\mathrm{SO}_{2}+\mathrm{NO}_{x}$ & 0.63 & 1.95 & 4.02 \\
\hline \multirow[t]{4}{*}{ Chernick (1989) } & $\mathrm{SO}_{2}$ & 0.00 & 1.00 & 2.00 \\
\hline & $\mathrm{NO}_{x}$ & 0.63 & 0.60 & 1.33 \\
\hline & $\mathrm{CO}_{2}$ & 1.38 & $\therefore .14$ & 2.60 \\
\hline & Total & 2.02 & 3.74 & 5.93 \\
\hline \multirow[t]{4}{*}{ Schilberg et al (1989) } & $\mathrm{SO}_{2}$ & 0.00 & 0.55 & 1.09 \\
\hline & $\mathrm{NO}_{x}$ & 0.54 & 0.51 & 1.14 \\
\hline & $\mathrm{CO}_{2}$ & 0.89 & 1.37 & 1.67 \\
\hline & Total & 1.43 & 2.43 & 3.90 \\
\hline \multirow[t]{4}{*}{ CA Outside SCAQMD } & $\mathrm{SO}_{2}$ & 0.00 & 0.98 & 1.96 \\
\hline & $\mathrm{NO}_{x}$ & 3.79 & 3.57 & 7.94 \\
\hline & $\mathrm{CO}_{2}$ & 0.89 & 1.37 & 1.67 \\
\hline & Total & 4.68 & 5.93 & 11.57 \\
\hline \multirow[t]{4}{*}{ CA Inside SCAQMD } & $\mathrm{SO}_{2}$ & 0.00 & 9.98 & 19.89 \\
\hline & $\mathrm{NO}_{x}$ & 4.94 & 4.65 & 10.35 \\
\hline & $\mathrm{CO}_{2}$ & 0.89 & 1.37 & 1.67 \\
\hline & Total & 5.82 & 16.00 & 31.92 \\
\hline \multirow[t]{4}{*}{ CEC Staff (CEC 1989) } & $\mathrm{SO}_{2}$ & 0.00 & 6.27 & 12.50 \\
\hline & $\mathrm{NO}_{x}$ & 2.34 & 2.20 & 4.90 \\
\hline & $\mathrm{CO}_{2}$ & 0.43 & 0.66 & 0.81 \\
\hline & Total & 2.76 & 9.13 & 18.21 \\
\hline \multirow{4}{*}{$\begin{array}{l}\text { Implied in Con Eci/NY Stale Bidding } \\
\text { System (NYPSC 1989b) }\end{array}$} & $\mathrm{SO}_{2}$ & 0.00 & 0.52 & 1.04 \\
\hline & $\mathrm{NO}_{x}$ & 0.38 & 0.36 & 0.79 \\
\hline & $\mathrm{CO}_{2}$ & 0.05 & 0.08 & 0.09 \\
\hline & Total & 0.43 & 0.96 & 1.93 \\
\hline
\end{tabular}

Sources: Hear Rates derived from NERC (1989). Electricity Price from USDOE (1989c) escalated at $5 \%$ to 1989\$. Emissions Factors are from Table A.2. T\&D losses $=6 \%$. Steam power plants generated roughly $99 \%$ of fossil-fired electricity in the U.S. in 1988, with the remainder being generated by combustion turbines.and internal combustion engines. 
TABLE 7. EXTERNALITIES FROM EXISTING U.S. STEAM POWER PLANTS (TOTAL AS \% OF 1988 ELECTRICITY PRICE)

\begin{tabular}{|c|c|c|c|}
\hline & Natural Gás & Oil & Coal \\
\hline $\operatorname{EPRI}(1987): \mathrm{SO}_{2}+\mathrm{NO}_{x}$ & $0.4 \%$ & $8.4 \%$ & $16.8 \%$ \\
\hline \multicolumn{4}{|l|}{ Hohmeyer (1988) } \\
\hline $\mathrm{SO}_{2}+\mathrm{NO}_{x}--$-LOW & $1.13 \%$ & $5.5 \%$ & $11.4 \%$ \\
\hline $\mathrm{SO}_{2}+\mathrm{NO}_{x}-\cdots \mathrm{High}$ & $9.5 \%$ & $29.4 \%$ & $60.7 \%$ \\
\hline Chizrnick (1989) & $30 \%$ & $76 \%$ & $90 \%$ \\
\hline \multicolumn{4}{|l|}{ Schilberg et al (1989) } \\
\hline Outside CA & $2: 2 \%$ & $37 \%$ & $59 \%$ \\
\hline CA Outside SCAQMD & $71 \%$ & $90 \%$ & $175 \%$ \\
\hline CA Inside SCAQMD & $88 \%$ & $242 \%$ & $483 \%$ \\
\hline CEC Staff (CEC 1989) & $42 \%$ & $138 \%$ & $275 \%$ \\
\hline Implied in NYPSC (1989b) & $6 \%$ & $14 \%$ & $29 \%$ \\
\hline
\end{tabular}

1988 U.S. Average Electricity Price $=6.6 \$ / \mathrm{kWh}(1989 \$)$. Steam power plants generatc $\mathrm{f}$ roughly $99 \%$ of fossil-fired electricity in the U.S. in 1988, with the remainder being generated by combustion turbines.and internal combustion engines. 
resource planning decisions substantially. 'To most accurately characterize the effects of such externality costs on these decisions requires use of a utility simulation model (Heslin and Hobbs 1989). These models can help determine average emissions factors for various pollutants, the regional distribution of releases from different power plants, and how these $\epsilon$ missions are affected by different dispatch strategies and future resource additions.

\section{Direct Combustion of Oil and Gas}

Table 8 shows calculated external costs from direct use of natural gas, and Table 9 shows the same for oil combustion. The 1988 U.S. average prices for the relevant fuels are included for comparison. Table 10 shows the estimates of total external costs as a percentage of the 1988 price. Direct combustion of natural gas is always assigned external costs less than the price of the fuel, which is not true for electricity use or direct use of oil. Direct use of oil is more damaging than gas, which is the result of higher emissions factors for oil in almost all cases.

These findings suggest that delivered heat from direct ccmbustion of natural gas has lower external costs than that associated with NSPS electricity generation using gas or other fuels. Consider the externality cost per delivered MMBtu of residential space heat from natural gas, assuming a combustion efficiency of $78 \%$. The CEC staif estimate irnplies external costs of $\$ 1.24 / \mathrm{MMBtu}$ of delivered heat. The external cost for electricity from a new NSPS gas combined-cycle plant is $1.39 \notin / \mathrm{kWh}$ or $\$ 4.07 / \mathrm{MMBtu}$ of delivered heat $(100 \%$ efficiency at point of use), which implies that the externality cost from electric space heat in this case is more than three times higher than the externality costs for direct use of natural gas. The environmental benefits of gas space heat are even greater when compared to electricity from existing plants or to that from new oil and coal plants. ${ }^{9}$

\section{DISCUSSION}

\section{The NY State Bidding Systems}

The NY State Bidding systems have been widely quoted as assigning an externality cost of $24 \%$ of avoided costs in NY State. However, only the most polluting resources (e.g., coal) under the worst possible circumstances are assigned this cost. A coal plant in a favorable location that utilizes existing infrastructure will have lower externalities than would such a facility in the worst case. Estimates derived from this system for typical new NSPS power plants are between 0.46 and $1.27 \varnothing / \mathrm{kWh}$, depending on the fuel and technology (see Table 4). Care should therefore be used in interpreting the implications of the NYPSC's externality weighting scheme.

9 Using a condensing gas iumace (efficiency 95\%) will increase this differential, while using best available control technology for power plants (usually selective catalytic reduction for NOX) will reduce it. 
TABLE 8. EXTERNALITIES FROM DIRECT USE OF NATURAL GAS

\begin{tabular}{|c|c|c|c|c|c|}
\hline \multicolumn{2}{|c|}{1989 S/MMBtu fuel Input } & $\begin{array}{l}\text { Home } \\
\text { Gas SH }\end{array}$ & $\begin{array}{l}\text { Home } \\
\text { Gas WH }\end{array}$ & $\begin{array}{c}\text { Comml } \\
\text { Gas } \\
\text { Bnller }\end{array}$ & $\begin{array}{l}\text { Industrlal } \\
\text { Gas Boller }\end{array}$ \\
\hline \multicolumn{2}{|l|}{1988 U.S. Avg. Price } & 5.56 & 5.56 & $\overline{72}$ & 3.01 \\
\hline \multirow[t]{3}{*}{ EPRI (1987) } & $\mathrm{SO}_{2}$ & 0.000 & 0.000 & 0.000 & 0.000 \\
\hline & $\mathrm{NO}_{X}$ & 0.007 & 0.008 & 0.007 & 0.010 \\
\hline & $\mathrm{SO}_{2}+\mathrm{NO}_{x}$ & 0.007 & 0.008 & 0.007 & 0.010 \\
\hline \multirow[t]{3}{*}{ Hohmeyer (1988) Low } & $\mathrm{SO}_{2}$ & 0.000 & 0.000 & 0.000 & 0.000 \\
\hline & $\mathrm{NO}_{x}$ & 0.029 & 0.032 & 0.029 & 0.041 \\
\hline & $\mathrm{SO}_{2}+\mathrm{NO}_{x}$ & 0.029 & 0.032 & 0.029 & 0.041 \\
\hline \multirow[t]{3}{*}{ High } & SO? & 0.000 & 0.000 & 0.000 & 0.000 \\
\hline & $\mathrm{NO}_{x}$ & 0.156 & 0.171 & 0.156 & 0.218 \\
\hline & $S O_{2}+N O_{x}$ & 0.156 & 0.171 & 0.156 & 0.218 \\
\hline \multirow[t]{4}{*}{ Chernick ef al. (1989) } & $\mathrm{SO}_{2}$ & 0.000 & 0.000 & 0.000 & 0.000 \\
\hline & $\mathrm{NO}_{x}$ & 0.158 & 0.173 & 0.158 & 0.221 \\
\hline & $\mathrm{CO}_{2}$ & 1.260 & 1.260 & 1.260 & 1.260 \\
\hline & Total & 1.42 & 1.43 & 1.42 & 1.48 \\
\hline \multirow{4}{*}{$\begin{array}{r}\text { Schilberg et al. (1989) } \\
\text { Outside CA }\end{array}$} & $\mathrm{SO}_{2}$ & 0.00 & 0.00 & 0.00 & 0.00 \\
\hline & $N O_{x}$ & 0.14 & 0.15 & 0.14 & 0.19 \\
\hline & $\mathrm{CO}_{2}$ & 0.81 & 0.81 & 0.81 & 0.81 \\
\hline & Total & 0.95 & 0.96 & 0.95 & 1.00 \\
\hline \multirow[t]{4}{*}{ CA Outside SCAQMD } & $\mathrm{SO}_{2}$ & 0.00 & 0.00 & 0.00 & 0.00 \\
\hline & $\mathrm{NO}_{x}$ & 0.94 & 1.03 & 0.94 & 1.32 \\
\hline & $\mathrm{CO}_{2}$ & 0.81 & 0.81 & 0.81 & 0.81 \\
\hline & Total & 1.75 & 1.84 & 1.75 & 2.13 \\
\hline \multirow[t]{4}{*}{ CA Inside SCAQMD } & $\mathrm{SO}_{2}$ & 0.00 & 0.00 & 0.00 & 0.00 \\
\hline & $\mathrm{NO}_{x}$ & 1.23 & 1.35 & 1.23 & 1.72 \\
\hline & $\mathrm{CO}_{2}$ & 0.81 & 0.81 & 0.81 & 0.81 \\
\hline & Total & 2.04 & 2.16 & 2.04 & 2.53 \\
\hline \multirow[t]{4}{*}{ CEC StaH (CEC 1989) } & $\mathrm{SO}_{2}$ & 0.00 & 0.00 & 0.00 & 0.00 \\
\hline & $\mathrm{NO}_{x}$ & 0.58 & 0.64 & 0.58 & $\hat{0} .81$ \\
\hline & $\mathrm{CO}_{2}$ & 0.39 & 0.39 & 0.39 & 0.39 \\
\hline & Total & 0.97 & 1.03 & 0.97 & 1.20 \\
\hline Implied in Con Ed/NYPSC & $\mathrm{SO}_{2}$ & 0.00 & 0.00 & 0.00 & 0.00 \\
\hline \multirow[t]{3}{*}{ Biclding System (1989b) } & $\mathrm{NO}_{x}$ & 0.09 & 0.10 & 0.09 & 0.13 \\
\hline & $\mathrm{CO}_{2}$ & 0.05 & 0.05 & 0.05 & 0.05 \\
\hline & Total & 0.14 & 0.15 & 0.14 & 0.18 \\
\hline NRDC (1989) & $\mathrm{CO}_{2}$ & 0.50 & 0.50 & 0.42 & 0.27 \\
\hline
\end{tabular}

To calculate externalities per MMBtu of delivered heat, divide these estimates by combustion/heat delivery efficiency. $\mathrm{WH}=$ Water Heat, $\mathrm{SH}=$ Space heat. 
TABLE 9. EXTERNALITIES FROM DIRECT USE OF OIL

\begin{tabular}{|c|c|c|c|c|}
\hline 1989 \$/MMBtu fuel & Input & $\begin{array}{l}\text { MF \#2 } \\
\text { Oil Boller }\end{array}$ & $\begin{array}{l}\text { Comml \#2 } \\
\text { Oll Boller }\end{array}$ & $\begin{array}{l}\text { Com/lnd.\#6 } \\
\text { Oll Boller }\end{array}$ \\
\hline \multicolumn{2}{|l|}{1988 U.S. Avg. Price } & 4.12 & 4.12 & 2.34 \\
\hline \multirow[t]{3}{*}{ EPRI (1987) } & $\mathrm{SO}_{2}$ & 0.152 & 0.152 & 0.524 \\
\hline & $\mathrm{NO}_{x}$ & 0.009 & 0.010 & 0.025 \\
\hline & $\mathrm{SO}_{2}+\mathrm{NO}_{x}$ & 0.160 & 0.162 & 0.550 \\
\hline \multirow[t]{6}{*}{ Hohmeyer (1988) } & $\mathrm{SO}_{2}$ & 0.073 & 0.073 & 0.252 \\
\hline & $\mathrm{NO}_{x}$ & 0.037 & 0.043 & 0.107 \\
\hline & $\mathrm{SO}_{2}+\mathrm{NO}_{x}$ & 0.110 & 0.116 & 0.360 \\
\hline & $\mathrm{SO}_{2}$ & 0.389 & 0.389 & 1.344 \\
\hline & $\mathrm{NO}_{X}$ & 0.199 & 0.227 & 0.571 \\
\hline & $\mathrm{SO}_{2}+\mathrm{NO}_{x}$ & 0.588 & 0.616 & 1.915 \\
\hline \multirow[t]{4}{*}{ Chernick et al. (1989) } & $\mathrm{SO}_{2}$ & 0.287 & 0.287 & 0.993 \\
\hline & $\mathrm{NO}_{x}$ & 0.202 & 0.230 & 0.578 \\
\hline & $\mathrm{CO}_{2}$ & 1.932 & 1.932 & 1.848 \\
\hline & Total & 2.42 & 2.45 & 3.42 \\
\hline \multirow{4}{*}{$\begin{array}{r}\text { Schilberg et al. (1989) } \\
\text { Outside CA }\end{array}$} & $\mathrm{SO}_{2}$ & 0.16 & 0.16 & 0.5 .4 \\
\hline & $\mathrm{NO}_{x}$ & 0.17 & 0.20 & 0.50 \\
\hline & $\mathrm{CO}_{2}$ & 1.24 & 1.24 & 1.19 \\
\hline & Total & 1.57 & 1.60 & 2.22 \\
\hline \multirow[t]{4}{*}{ CA Outside SCAQMD } & $\mathrm{SO}_{2}$ & 0.28 & 0.28 & 0.97 \\
\hline & $\mathrm{NO}_{\mathrm{X}}$ & 1.20 & 1.37 & 3.45 \\
\hline & $\mathrm{CO}_{2}$ & 1.24 & 1.24 & 1.19 \\
\hline & Totai & 2.73 & 2.90 & 5.61 \\
\hline \multirow[t]{4}{*}{ CA Inside SCAQMD } & $\mathrm{SO}_{2}$ & 2.86 & 2.86 & 9.89 \\
\hline & $\mathrm{NO}_{x}$ & 1.57 & 1.79 & 4.50 \\
\hline & $\mathrm{CO}_{2}$ & 1.24 & 1.24 & 1.19 \\
\hline & Total & 5.67 & 5.89 & 15.58 \\
\hline \multirow[t]{4}{*}{ CEC Staff (CEC 1989) } & $\mathrm{SO}_{2}$ & 1.80 & 1.80 & 6.22 \\
\hline & $\mathrm{NO}_{x}$ & 0.74 & 0.85 & 2.13 \\
\hline & $\mathrm{CO}_{2}$ & 0.60 & 0.60 & 0.57 \\
\hline & Total & 3.14 & 3.24 & 8.92 \\
\hline Implied in Con Ed/NYPSC & $\mathrm{SO}_{2}$ & 0.15 & 0.15 & 0.52 \\
\hline \multirow[t]{3}{*}{ Bidding System (1989b) } & $\mathrm{NO}_{x}$ & 0.12 & 0.14 & 0.34 \\
\hline & $\mathrm{CO}_{2}$ & 0.07 & 0.07 & 0.07 \\
\hline & Total & 0.34 & 0.36 & 0.93 \\
\hline NREC (1989) & $\mathrm{CO}_{2}$ & 0.49 & 0.49 & 0.28 \\
\hline
\end{tabular}


TABLE 10. EXTERNALITIES FROM DIRECT USE OF FOSSIL FUELS (TOTAL AS $\%$ OF 1988 PRICE)

\begin{tabular}{|c|c|c|c|c|}
\hline NATURAL GAS & $\begin{array}{c}\text { Resldentlal } \\
\text { Gas SH }\end{array}$ & $\begin{array}{c}\text { Residentlal } \\
\text { Gas Whi }\end{array}$ & $\begin{array}{c}\text { Commerclal } \\
\text { Gas Boller }\end{array}$ & $\begin{array}{l}\text { Industrlal } \\
\text { Gas Boller }\end{array}$ \\
\hline 1988 Price (89\$/MMBtu) & 5.56 & 5.56 & 4.72 & 3.01 \\
\hline EPRI $(1987): \mathrm{SO}_{2}+\mathrm{NO}_{\mathrm{x}}$ & $0.1 \%$ & $0.1 \%$ & $0.1 \%$ & $0.3 \%$ \\
\hline Hohmeyer (1988) & & & & \\
\hline $\mathrm{SO}_{2}+\mathrm{NO}_{x}-$ LOW & $0.5 \%$ & $0.6 \%$ & $0.6 \%$ & $1.4 \%$ \\
\hline $\mathrm{SO}_{2}+\mathrm{NO}_{x}-$-High & $2.8 \%$ & $3.1 \%$ & $3.3 \%$ & $7.2 \%$ \\
\hline Chernick et al. (1989) & $25 \%$ & $26 \%$ & $30 \%$ & $49 \%$ \\
\hline Schilberg et al. (1989) & & & & \\
\hline Qutside CA & $17 \%$ & $17 \%$ & $20 \%$ & $33 \%$ \\
\hline CA Outside SCAQMD & $31 \%$ & $33 \%$ & $37 \%$ & $71 \%$ \\
\hline CA Inside SCAQMD & $37 \%$ & $39 \%$ & $43 \%$ & $84 \%$ \\
\hline CEC Staff (CEC 1989) & $17 \%$ & $18 \%$ & $21 \%$ & $40 \%$ \\
\hline Implied in NYPSC(1989b) & $3 \%$ & $3 \%$ & $3 \%$ & $6 \%$ \\
\hline NRDC (1989) & $9 \%$ & $j \%$ & $9 \%$ & $9 \%$ \\
\hline OIL & $\begin{array}{c}\text { MF \#2 } \\
\text { Oll Boller }\end{array}$ & $\begin{array}{l}\text { Comml \#2 } \\
\text { Oll Boller }\end{array}$ & $\begin{array}{c}\text { Com/lind. \#6 } \\
\text { Oll Boller }\end{array}$ & \\
\hline 1988 Price $(89 \$ / \mathrm{MMBtu})$ & 4.12 & 4.12 & 2.34 & \\
\hline EPRI (1987): $\mathrm{SO}_{2}+\mathrm{NO}_{x}$ & $3.9 \%$ & $3.9 \%$ & $23.5 \%$ & \\
\hline Hohmeyer (1988) & & & & \\
\hline $\mathrm{SO}_{2}+\mathrm{NO}_{x}-$ LOW & $2.7 \%$ & $2.8 \%$ & $15.4 \%$ & \\
\hline $\mathrm{SO}_{2}+\mathrm{NO}_{x}-\mathrm{High}$ & $14.3 \%$ & $15.0 \%$ & $81.8 \%$ & \\
\hline Chernick et al. (1989) & $59 \%$ & $44 \%$ & $73 \%$ & \\
\hline Schilberg et al. (1989) & & & & \\
\hline Outside CA & $38 \%$ & $39 \%$ & $95 \%$ & \\
\hline CA Outside SCAQMD & $66 \%$ & $70 \%$ & $240 \%$ & \\
\hline CA Inside SCAQMD & $138 \%$ & $143 \%$ & $665 \%$ & \\
\hline CEC Staff (CEC 1989) & $76 \%$ & $79 \%$ & $381 \%$ & \\
\hline Implied in NYPSC(1989b) & $8 \%$ & $9 \%$ & $40 \%$ & \\
\hline NRDC (1989) & $12 \%$ & $12 \%$ & $12 \%$ & \\
\hline
\end{tabular}




\section{Site-Specificity of Damages}

Many externalities are strongly site specific and dependent on particular circumstances, so comparisons and generalizations should be attempted only with caution. For instance, power plants that use existing infrastructure (power lines, pipelines, etc.) will have fewer environmental impacts than those that require construction of new infrastructure. Pollution in ruial areas will have far different impacts than pollution in urban areas, although the total societal costs may in some cases be comparable.

New York State's bidding systems acknowledge this complexity in land and water use issues, but do not do so for air pollution. Approaches that have been adopted by other regulatory bodies are even less accurate in characterizing geographic variations. This omission is a key area for improvement. Regulators should differentiate between air emissions in rural, suburban, and urban areas, because damages can vary widely among such locales.

\section{Resource Cost and Externalities}

The NPPC's conservation adder and the PSCWI's non-combustion credit are path-breaking contributions to resource planning. However, using such techniques implicitly assumes that resource cost is a good measure of externality costs. Environmental and human health damages from pollution are usually strongly correlated with fuel type, air emissions, heat rates, and other operating characteristics of power plants, and have little relation to resource cost. Resource planning estimates of externalities that are based on a percentage of the busbar cost of the resource can therefore lead to perverse results. ${ }^{10}$

For instance, using NPPC's 10\% cost adder to differentiate between external costs of new supply resources implies that a new NSPS coal plant has external costs only $50 \%$ higher than a gas-fired combined cycle (CC) plant that emits no sulfur and has an efficiency $14 \%$ higher than the coal plant. Other estimates (e.g., 1-6 in Table 4) typically indicate that externality costs from this new coal plant are two to four times larger than those from the CC gas plant. The NRDC r.roposal is an improvement over the single percentage adder, but it still ignores power plant heat rates and depends upon resource cost.

The NYPSC bidding system, which represents a great step forward in treating externalities explicitly in resource acquisition, depends indirectly upon

\footnotetext{
${ }^{10}$ Comparisons between different estimates based on a perceritage of a resource's cost can be instructive, but the estimates themselves should not be based on such percentages. The "resource cost" of increasing output at existing plants is equal to the short-run variable costs, which are much lower than the total delivered costs of a new resource. In addition, existing plants are usually far more polluting than new plants of the same type. Basing estimates of externality costs on a fixed percentage of resource costs will be even more misleading in this case.
} 
resource cost. The total value of externalities is fixed $(1.405 \mathrm{c} / \mathrm{kWh})$ and this value is distributed depending upon the number of points assigned to a given pollutant. This sysiem is an improvement over other regulatory determinations because it is far more detailed, but its reliance on resource cost may lead to inappropriate ranking of bids in the future.

\section{Global Warming}

Several attempts have been made to quantify the cost of global warming, either through direct cost estimation (Cavanagh et al. 1982) or through proxy methods (CEC Staff 1989, Chernick and Caverhill 1989, Schilberg et al. 1989). Direct damage calculations for this phenomenon are especially difficult because regional forecasts of climate change are even less certain than the global predictions, yet regional forecasts are necessary to estimate damages (Krause et al. 1989). Proxy approaches are also problematic since many global warming mitigation measures have multiple benefits (Krause and Koomey 1989), and many of these measures await detailed, consistent tabulation.

In spite of these uncertainties, one important conclusion emerges: all emissions that contribute to global warming should be treated similarly. Carbon, which is the most important contributor to the global warming problem, is by no means the only one. Radiatively active trace gases like methane $\left(\mathrm{CH}_{4}\right)$, nitrous oxide ( $\left.\mathrm{N}_{2} \mathrm{O}\right)$, and chlorotiourocarbons (CFCs) should all be assigned the same externality cost per unit of global warming contribution. The appendices in Krause et al. (1989) explain how to convert concentrations of the other gases into equivalent $\mathrm{CO}_{2}$ concentrations, which can then be used to assign these gases externality costs (once the appropriate cost for $\mathrm{CO}_{2}$ has been determined). Others have also derived "warming factors" that can be used to achieve the same result (e.g., Unnasch et al. (1989) and DeLuchi et al. (1987a)).

\section{Assumptions}

Because the choice of a value for externalities is necessarily subjective, it is essential that important input assumptions be made explicit. The cost per pound of pollutant emitted (or per other physical unit of insult) should be a primary input to the calculation of the external cost of a given technology, and should always be stated clearly. Geographic and system boundaries should be consistent for different technologies, as inclusive as possible, and explicitly documented.

\section{The Need for Consistent Emissions Factors}

This analysis highlights the need for a consistent, comprehensive, regional database of emissions factors for new and existing U.S. power plants, as well as for direct combustion. The more common pollutants have well known emissions rates. Others, like $\mathrm{N}_{2} \mathrm{O}$, particulates, and reactive organic gases, are not as well known. A complete treatment must include emissions from all stages of energy production and use, for a large number of different technologies and all relevant fuels. 


\section{CONCLUSIONS}

Current estimates of the societal costs of electric power and direct combustion of fossil fuels can be substantial fractions of the cost or price of the corresponding rusources. Regional complexities make generalizations difficult. these complexities should be accommodated to the greatest extent possible when designing policies to incorporate societal costs in ratemaking and utility resource planning. Uncertainties in such calculations are large and should be made explicit.

Regulatory assessments of the size of externalities for the new power plants considered here range from 3 to $15 \%$, while the abatement cost analyses considered here generally yield estimates that are higher than the regulatory determinations as a percentage of resource costs. Externality costs from existing power plants are probably large enough to influence utility dispatch decisions. Externality costs for direct combustion of natural gas for water or space heat are substantially lower than externality costs associated with using fossil-fueled electricity for this purpose.

Policies that calculate externalities based on a percentase of resource costs submerge important details and should be avoided in the future. Damages from pollutants are not, in general, correlated with resource costs, but are strongly related to pollutant emissions, local topography, population density, and other physical characteristics of the surrounding area.

\section{ACKNOWLEDGEMENTS}

I wish to thank the following colleagues for their substantive assistance with this paper and related work: Chuck Goldman, Joe Eto, and Florentin Krause of Lawrence Berkeley Laboratory, Ken Schafer and John Beldock of the U.S. Department of Energy. Beth Schwehr of the California Air Resources Board, Deborah Gordon of the Union of Concerned Scientists, Chris Calwell of the Natural Resources Defense Council, Paul Chernick and Emily Caverhill of PLC, Inc., Dick Ottinger of Pace University, Allan Edwards and Kari Smith of the California Energy Commission, John Smolinsky and Sury Putta of the NYPSC, Sarah Jenkins of the PSCWI, Olav Hohmeyer at the Fraunhoier Institute, Kurt Janson at the Vermont Public Service Board and Margie Gardner of the NPPC. I alone am responsible for the analysis presented here and any errors contained within.

The work described in this paper was funded by the Assistant Secretary for Conservation and Renewable Energy, Office of Utility Technologies of the U.S. Department of Energy, under Contract No. DE-AC03.76SF00038 


\section{REFERENCES}

Burkhart, Lori A. 1989. "External Social Costs as a Factor in Least-cost Planning -- An Emerging Concept". Public Utilities Fortnightly. August 31.. p. 43.

Cavanagh, Ralph, Margie Gardner and David Goldstein. 1982. "Part IIIA2E: Environmental Costs." In A Model Electric Power and Conservation Plan for the Pacific Northwest. Northwest Conservation Act Coalition.

CEC Staff, Energy Facility Siting and Environmental Protection Division. 1989. Valuing Emission Reductions for Electricity Report 90. California Energy Commission. Staff Issue Paper \#3R, Docket \# 88-ER-8. November 21.

Chernick, Paul and Emily Caverhill. 1989. The Valuation of Externalities From Energy Production, Delivery, and Use: Fall 1989 Update. A Report by PLC, Inc. to the Boston Gas Co. December 22.

Cohen, S. D., J. H. Eto, C. A. Goldman, J. Beldock and G. Crandall. 1990. A Survey of State PUC Activities to Incorporate Environmental Externalities into Electric Utility Planning and Regulation. Prepared by Lawrence Berkeley Laboratory for the National Association of Regulatory Utility Commissioners (NARUC). May.

Cooper, C. David and F. C. Alley. 1986. Air Pollution Control: A Design Approach. Boston, MA: PWS Engineering.

DeLuchi, Mark A., Robert A. Johnston and Daniel Sperling. 1987a. Transportation Fuels and the Greenhouse Effect. University-Wide Energy Research Group, University of California. UER-182. December.

Deluchi, Mark A., Daniel Sperling and Robert A. Johnston. 1987b. A Comparative Analysis of Future Transportation Fuels. Institute of Transportation Studies, University of California, Berkeley. UCB-ITS-RR87-13. October.

Electric Power Research Institute (EPRI). 1986. TAG-Technical Assessment Guide: Vol. 1: Electricity Supply-1986. EPRI. EPRI P-4463-SR. December.

Electric Power Research Institute (EPRI). 1987. TAG-Technical Assessment Guide: Vol. 4: F!ındamentals and Methods, End Use. EPRI. EPRI P. 4463-SR, vol.4. August .

Gleick, Peter H., Gregory P. Morris and Nicki A. Norman. 1989. Greenhouse Gas Emissions from the Operation of Energy Facilities. Independent Energy Producers Association, Sacramento, CA. July 22.

Griffin, James M. and Henry B. Steele. 1986. Energy Economics and Policy. 2nd edition, Orlando, FL: Academic Press College Division.

Harte, Juhn. 1985. Consider a Spherical Cow: A Course in Environmental Problem Solving. Los Altos, CA: William Kaufmann, Inc.

Heslir', James S. and Benjamin F. Hobbs. 1989. "A Multiobjective Production "Sosting Model for Analyzing Emissions Dispatching and Fuel Switching." IEEE Transactions on Power Systems. vol. 4 , no. 3. 
Hohmeyer, O. 1988. Social Costs of Energy Consumption: External Effects of Electricity Generation in the Federal Republic of Germany. Berlin: Springer-Verlag.

Hohmeyer, O. 1990. Personal Communication (via fax): "Memo to Florentin Krause, LBL, detailing external costs per unit mass of carbon monoxide, particulates, NOx, SO2, and VOC". Fraunhofer-Institut, West Germany. February 2.

Holdren, John P. 1980. Integrated Assessment for Energy-Related Environmental Standards: A Summary of Issues and Findings. Lawrence Berkeley Laboratory. LBL-12779. October.

Holdren, John P. 1981. "Chapter V. Energy and Human Environment: The Generation and Definition of Environmental Problems." In The European Transition from Oil: Societal Impacts and Constraints on Energy Policy. Edited by G. T. Goodman, L. A. Kristoferson and J. M. Hollander. London: Academic Press.

Hupa, Mikko, Rainer Backman and Sture Bostrom. 1989. "Nitrogen Oxide Emissions of Boilers in Finland." JAPCA Journal. vol. 39, no. 11. p. 1496.

Kahn, Edward. 1988. Electric Utility Planning and Regulation. Washington, DC: American Council for an Energy-Efficient Economy.

Krause, Florentin, Wilfred Bach and Jon Koomey. 1989. Energy Policy in the Greenhouse. Volume 1. From Warming Fate to Warming Limit: Benchmarks to a Global Climate Convention. El Cerrito, CA: International Project for Sustainable Energy Paths.

Krause, Florentin and Jon Koomey. 1989. "Unit Costs of Carbon Savings From Urban Trees, Rural Trees, and Electricity Demand-Side Resources". Presented at Conference on Urban Heat Islands, February 23-24, in Berkeley, California.

Marcus, William B. 1989. Prepared Testimony of William B. Marcus on Marginal Cost and Revenue Allocation. Testimony Before the California Public Utilities Commission. App. 88-12-005. April 13.

Meridian Corp. 1989. Energy System Emissions and Materiel Requirements. The Deputy Assistant Secretary for Renewable Energy, U.S. Department of Energy. February.

North-American Electric Reliability Council (NERC). 1989. 1989 Electricity Supply and Demand for 1989-98. NERC. October.

Northwest Power Planning Council (NPPC). 1989. Accounting for the Environmental Consequences of Electricity Resources During the Power Planning Process. Issue Paper 89-7. April 17.

Natural Resources Defense Council (NRDC). 1989. Personal Communication: "NRDC Proposal to California's Collaborative Process on Quantifying the Environmental Benefits of Energy Savings". November 20.

New York Public Service Commission (NYPSC). 1989a. Opinion and Order Establishing Guidelines for Bidding Program--Case 88-E-241.- 
Proceeding on Motion of the Commission (established in Opinion No. 8815) as to the guidelines for bidding to meet future electric capacity needs of Orange and Rockland Utilities, Inc. 89-7. April 13.

New York Public Service Commission (NYPSC). 1989b. Order Issuing a Final Environmental Impact Statement--Case 88-E-246--Proceeding on Motion of the Commission (established in Opinion No. 88-15) as to the guidelines for bidding to meet future electric needs of Consolidated Edison Company of New York, Inc. July 19.

Ottinger, Richard L., Nicholas A. Robinson, Susan E. Babb, David R. Wooley, David R. Hodas, Shepard C. Buchanan, Paul L. Chernick, Emily Caverhill, Judith A. Meltzer, Alan Krupnick, Winston Harrington and Sari Radin. 1990. Environmental Externality Costs from Electric Utility Operations. N.Y. State Energy Research and Development Authority and the U.S. Department of Energy. Draft Final Report. February 28.

Public Service Commission of Wisconsin (PSCWI). 1989. Findings of Fact, Conclusion of Law and Order, Advance Plan 5, Docket 05-EP-5. April 6.

Schilberg, G. M., J. A. Nahigian and W. B. Marcus. 1989. Valuing Reductions in Air Emissions and Incorporation into Electric Resource Planning: Theoretical and Quantitative Aspects (re: CEC Docket 88-ER-8). JBS Energy, Inc, for the Independent Energy Producers. August 25.

US Environmental Protection Agency (USEPA). 1979. "National Source Performance Standards." Federal Register. vol. 44, no. p. 33580.

Unnasch, Stefan, Carl B. Moyer, Douglas D. Lowell and Michael D. Jackson. 1989. Comparing the Impact of Different Transportation Fuels on the Greenhouse Effect. Report to the California Energy Commission. P50089-001. April.

US Department of Energy (USDOE). 1989a. Electric Power Annual 1988. Energy Information Administration. DOE/EIA-0348(88). December.

US Department of Energy (USDOE). 1989b. Annual Energy Outlook: LongTerm Projections 1989. Energy Information Administration. DOE/EIA0383(89).

US Department of Energy (USDOE). 1989c. Monthly Energy Review, February 1989. Energy Information Administration. DOE/ElA-0035(89/02). May.

Vermont Public Service Board (VTPSB). 1990. Docket \#5270, "Investigation into Least-Cost Investments, Energy Efficiency, Conservation, and Mrnagement of Cemand for Energy". Vol. 4, pp. 9-14. Order entered April 16th. 


\section{APPENDIX A. INPUT ASSUMPTIONS}

\section{Emissions Factors}

Table A.1 shows emissions factors for $\mathrm{SO}_{2}, \mathrm{NO}_{x}$, and $\mathrm{CO}_{2}$ for five types of new power plant technology, existing natural gas, oil, and coal power plants, and seven types of direct combustion of gas and oil. I have expressed these emissions factors in pounds of pollutant per MMBtu of fuel input. This approach is helpful because it produces emissions factors that are independent of assumptions about power plant heat rates.

The sulfur emissions for oil and coal are calculated as shown in Table A.2, with the uncontrolled emissions factors corresponding to those for direct combustion (assuming an uncontrolled release fraction of $100 \%$ ), and the controlled emissions factors corresponding to those from power plant combustion meeting the 1979 National New Source Performance Standards (iNSPS) (Cooper and Alley 1986, USEPA 1979). The NOx emissions factors for new power plants correspond to the NSPS values for all cases. The emissions factors for existing power plants are derived from USDOE (1989a). The NOx emissions factors are consistent with recent estimates of such factors for existing plants in Finland (Hupa et al. 1989). The $\mathrm{NO}_{x}$ emissions factors for direct combustion (and all $\mathrm{CO}_{2}$ emissions factors) are from Chernick (1989).

\section{Power Plant Cost Assumptions}

Table A.3 shows the delivered cost (including transmission and distribution losses) of five new supply technologies based on data from the Electric Power Research Institute's Technical Assessment Guide (EPRI 1986). I used these delivered costs to calculate the total external costs implied by the Northwest Power Planning Council's 10\% cost adder and the NRDC's $\mathrm{CO}_{2}$ adders. The value of Wisconsin's $15 \%$ credit for demand-side management (DSM) technologies was calculated for two cases; one in which DSM costs half of the corresponding supply technology, and one in which it costs the same as the corresponding supply technology.

The capital cost of the power plants includes a $20 \%$ reserve margin adjustment. The nominal fixed charge rate (FCR) for a 30 year lifetime was derived using the tax multiplier method (Kahn 1988), EPRl's typical capital structure (EPRI 1986), a 6.1\% real discount rate, and a state plus federal tax rate of $38 \%$. The FCR for a 40 year lifetime was approximated by calculating the ratio of the Capital Recovery Factor (CRF) using $6.1 \%$ real discount rate for a thirty year lifetime to that for $6.1 \%$ and a forty year lifetime, and multiplying this ratio by the 30 year FCR. Fuel Prices are levelized values (1988-2000) from the USDOE's Annual Energy Outlook (USDOE 1989b). 
TABLE A.1. EMISSIONS FACTORS (I.BS/MMBTU OF FUEL USE)

\begin{tabular}{|l|c|c|c|}
\hline New NSPS Power Plants & $\begin{array}{c}\mathrm{SO}_{2} \\
\text { lbs } \mathrm{SO}_{2}\end{array}$ & $\begin{array}{c}\mathrm{NO}_{x} \\
\text { lbs NO}\end{array}$ & $\begin{array}{c}\mathrm{CO}_{2} \\
\mathrm{lbs} C\end{array}$ \\
\hline CC Gas & 0.00 & 0.20 & 30.00 \\
CT Gas & 0.00 & 0.20 & 30.00 \\
CC Oil (\#6 Residual) & 0.20 & 0.20 & 46.00 \\
CT Oil (\#2 Distillate) & 0.20 & 0.20 & 44.00 \\
Baseload Coal & 0.60 & 0.60 & 57.00 \\
\hline Existing Power Plants & & & \\
\hline Natural Gas & 0.00 & 0.37 & 30.00 \\
Oil & 0.94 & 0.33 & 44.00 \\
Coal & 2.00 & 0.78 & 57.00 \\
\hline Direct Combustion & & & \\
\hline Res. Gas Space Heater & 0.000 & 0.10 & 30.00 \\
Res. Gas Water Heater & 0.000 & 0.11 & 30.00 \\
Comm. Gas Boiler & 0.000 & 0.10 & 30.00 \\
Ind. Gas Boiler & 0.000 & 0.14 & 30.00 \\
Res. \#2 Oil Boiler & 0.313 & 0.13 & 46.00 \\
Comm. \#2 Oil Boiler & 0.313 & 0.15 & 46.00 \\
Com/nd \#6 Oil Boiler & 1.081 & 0.37 & 44.00 \\
\hline CO & & & \\
\hline
\end{tabular}

$\mathrm{CO}_{2}$ from Chernick and Caverhill (1989).

Sources for $\mathrm{NO}_{x}$ and $\mathrm{SO}_{2}$ :

New Power Plants: NSPS Values from Cooper (1986) and USEPA (1979)

Existing Power Plants: Derived from USDOE (1989a)

Direct fuel Use: Chernick and Caverhill (1989) and Table A.2 for sulfur emissions. 
TABLE A.2. CALCULATING SULFUR EMISSIONS FROM OIL AND COAL

\begin{tabular}{|c|c|c|c|}
\hline & \#2 Distillate Oil & \#6 Residual OII & $\begin{array}{l}\text { Utility } \\
\text { Coal }\end{array}$ \\
\hline kBtus/lb & 19.2 & 18.5 & 10.46 \\
\hline$\%$ Sulfur by Weight & $0.30 \%$ & $1.00 \%$ & $1.20 \%$ \\
\hline Lbs S/MMBtu No Controls & 0.156 & 0.541 & 1.147 \\
\hline Lbs $\mathrm{SO}_{2} / \mathrm{MMBtu}$ No Controls & 0.313 & 1.081 & 2.294 \\
\hline Lbs $\mathrm{SO}_{2} / \mathrm{MMBtu} w /$ Controls & 0.200 & 0.200 & 0.600 \\
\hline Reduction Fraction w/Controls & $36 \%$ & $82 \%$ & $74 \%$ \\
\hline
\end{tabular}

Heating Value of Coal is U.S. utility average from USDOE (1989c). Emissions Factors with controls are NSPS values. 
TABLE A.3. NEW SUPPLY TECHNOLOGIES

\begin{tabular}{|c|c|c|c|c|c|}
\hline DARAMETER & $\begin{array}{l}\mathrm{CC} \\
\mathrm{GAS}\end{array}$ & GAS & $\begin{array}{l}\text { CC } \\
\text { OIL }\end{array}$ & $\begin{array}{l}\mathrm{CT} \\
\text { OIL }\end{array}$ & $\begin{array}{l}\text { COAL } \\
\text { STEAM }\end{array}$ \\
\hline FIXED COSTS & & & & & \\
\hline Lifetime (Years) & 30 & 30 & 30 & 30 & 40 \\
\hline Nominal Fixed Charge Rate (FCR) & 0.168 & 0.168 & 0.168 & 0.168 & 0.154 \\
\hline Capital Cost $(\$ / \mathrm{kW})$ & 635 & 358 & 635 & 358 & 1460 \\
\hline Annualized Capital Cost (\$/kW/yr) & 106.67 & 60.12 & 106.67 & 60.12 & 224.86 \\
\hline Fixed O\&M $(\$ / k W / y r)$ & 8.543 & 0.519 & 8.543 & 0.519 & 23.204 \\
\hline Sum of Fixed Costs $(\$ / k W / y r)$ & 115.21 & 60.64 & 115.21 & 60.64 & 248.07 \\
\hline T\&D + Reserve Margin Adjustment & 1.272 & 1.272 & 1.272 & 1.272 & 1.272 \\
\hline ADJUSTED FIXED COSTS (\$/KW/YR) & 146.55 & 77.14 & 146.55 & 77.14 & 315.54 \\
\hline CAPACITY FACTOR & 0.65 & 0.1 & 0.65 & 0.1 & 0.65 \\
\hline ADJUSTED FIXED COSTS ( $\mathrm{e} / \mathrm{kWh})$ & 2.6 & 8.8 & 2.6 & 8.8 & 5.5 \\
\hline VARIABLE COSTS & & & & & \\
\hline Incremental O\&M ( $\$ / \mathrm{kWh})$ & 0.22 & 0.50 & 0.22 & 0.50 & 0.58 \\
\hline Heat Rate (Btus/kWh) & 8440 & 13900 & 8440 & 13900 & 9660 \\
\hline Fuel Price (\$/MMBtu) & 3.04 & 3.04 & 3.58 & 3.58 & 1.67 \\
\hline Fuel Cost $(\Phi / k W h)$ & 2.6 & 4.2 & 3.0 & 5.0 & 1.6 \\
\hline Sum of Variable Costs $(\varnothing / k W h)$ & 2.8 & 4.7 & 3.2 & 5.5 & 2.2 \\
\hline T\&D Adjustment & 1.06 & 1.06 & 1.06 & 1.06 & 1.06 \\
\hline ADJUSTED VARIABLE COSTS $(\varnothing / K W H)$ & 3.0 & 5.0 & 3.4 & 5.8 & 2.3 \\
\hline DELIVERED COST (C/KWH) & 5.5 & 13.8 & 6.0 & 14.6 & 7.9 \\
\hline
\end{tabular}

Source: Capital and O\&M costs--EPRI (1986); Fuel Prices are levelized values 1988-2000 from the USDOE (1989b).

Assumptions: T\&D losses $=6 \%$, Reservis Margin $=20 \%$, Real Discount Rate $=6.1 \%$. Nominal Fixed Charge Rate $=16.8 \%$. 30 year Fixed Charge Rate derived using Tax Multiplier Method (Kahn 1988), EPRI's typical utility capital structure (1986) and a State + Federal Tax Rate of $38 \%$; 40 year FCR approximated by calculating the ratio of the Capital Recovery Factor at $6.1 \%$ real and 40 years to that for $6.1 \%$ and 30 years, and multiplying this ratio by $16.8 \%$. All Costs are in $1989 \$$. $\mathrm{CC}=$ Combined Cycle, $\mathrm{CT}=$ Combustion Turbine; Coal Steam is a supercritical unit from EPRI (1986, p. B-33) 


\section{APPENDIX B. CALCULATING EXTERNAL COSTS USING THE NYPSC'S WORKSHEETS}

External costs were calculated using the NYPSC's worksheets for the Consolidated Edison Company. For each environmental impact, there is a point score and a weighting factor. Point scores range from one to five, while weighting factors range from one to nineteen. A non-polluting resource such as energy efficiency will receive the maximum number of points (240 points), which equals five times each weighting factor, summed over all environmental impacts. The number of points for each resource was subtracted from the maximum point value (240). This difference, divided by the maxim! $1 \mathrm{~m}$ point value, and multiplied by $1.405 \% / \mathrm{kWh}$ gives the externality cost for each resource in $₫ / k W h$.

To calculate the implicit value of $\mathrm{SO}_{2}$ emissions reductions shown in Table 3, the weighting factor for $\mathrm{SO}_{2}$ was multiplied by five points, divided by the total number of points for all externalities, and multiplied by $\$ 14.05 / \mathrm{MWh}$ $(1.405 ₫ / \mathrm{kWh})$. This number was divided by $6.01 \mathrm{lbs} / \mathrm{MWh}$ minus $0.49 \mathrm{lbs} / \mathrm{MWh}$, which represents the emissions reduction needed to capture all points allocated to $\mathrm{SO}_{2}$ emissions. $\mathrm{CO}_{2}, \mathrm{NO}_{x}$ and particulates were treated analogously. 

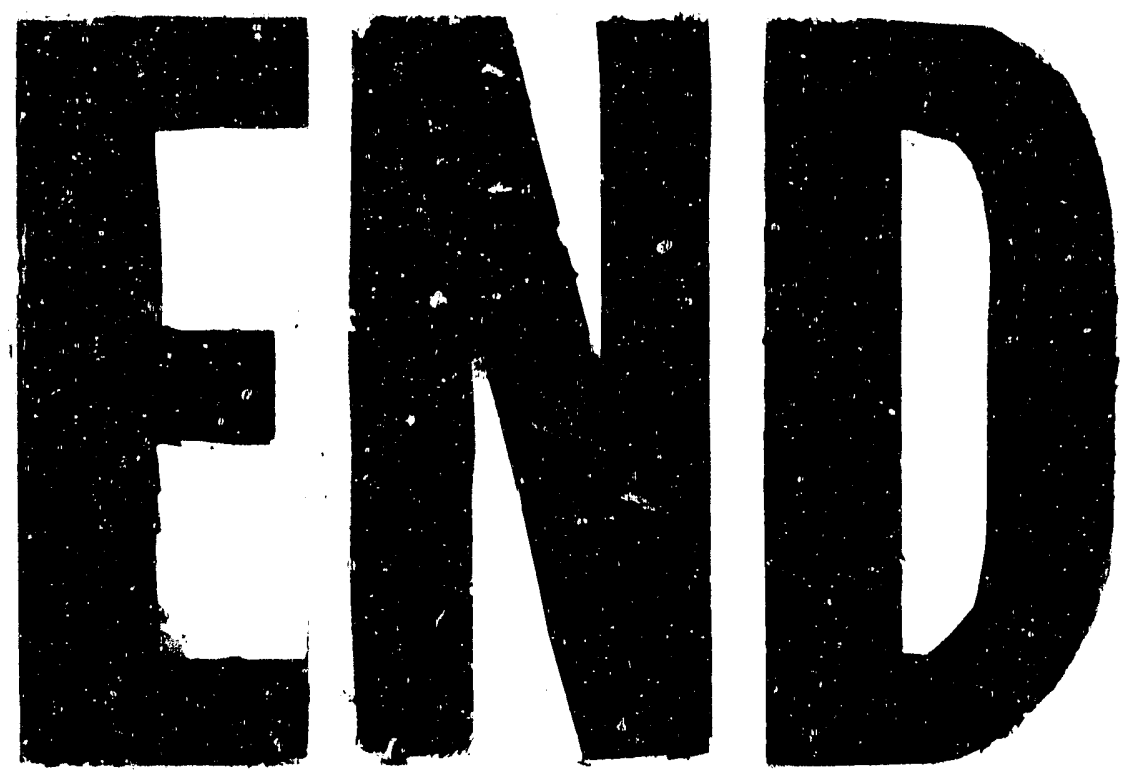

4
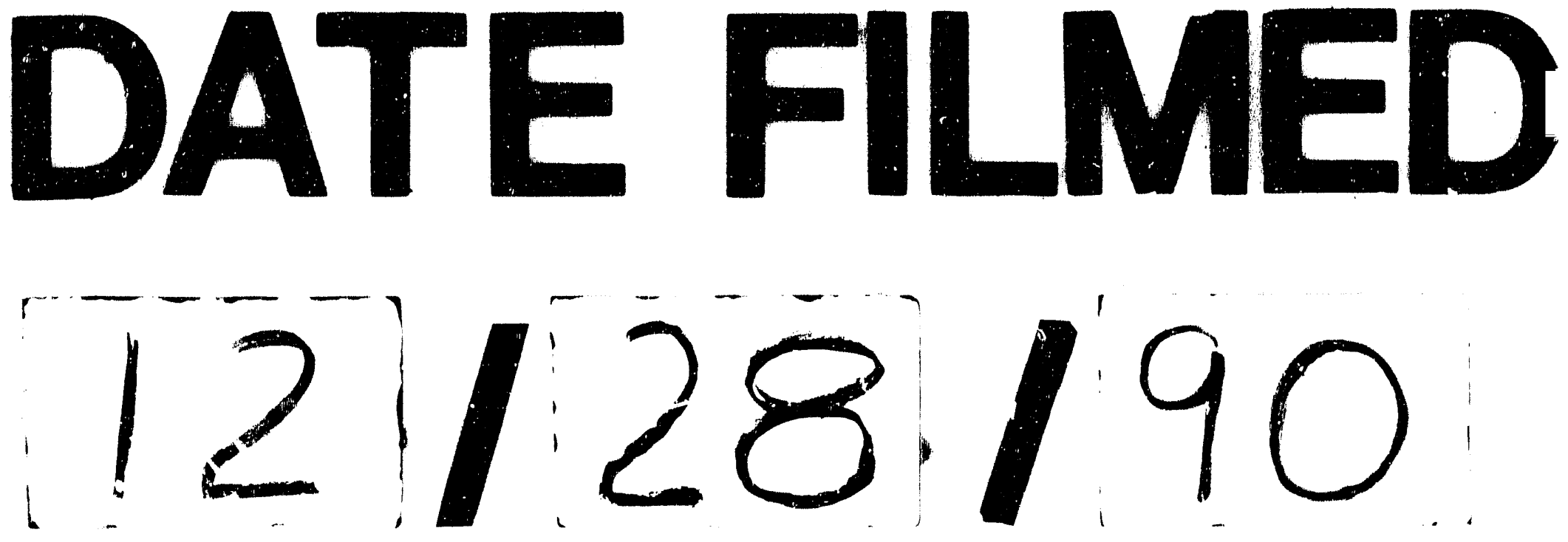
